\title{
Ubiquitin-Activating Enzyme Activity Contributes to Differential Accumulation of Mutant Huntingtin in Brain and Peripheral Tissues
}

\author{
Brandy E. Wade, ${ }^{1}$ Chuan-En Wang, ${ }^{1}$ Sen Yan, ${ }^{1,2}$ Kavita Bhat, ${ }^{1}$ Brenda Huang, ${ }^{1}$ Shihua Li, ${ }^{1}$ and Xiao-Jiang Li ${ }^{1,2}$ \\ ${ }^{1}$ Department of Human Genetics, Emory University School of Medicine, Atlanta, Georgia 30322, and ${ }^{2}$ State Key Laboratory of Molecular Developmental \\ Biology, Institute of Genetics and Developmental Biology, Chinese Academy of Sciences, Chaoyang District, Beijing 100101, People's Republic of China
}

\begin{abstract}
Huntington's disease (HD) belongs to a family of neurodegenerative diseases caused by misfolded proteins and shares the pathological hallmark of selective accumulation of misfolded proteins in neuronal cells. Polyglutamine expansion in the HD protein, huntingtin (Htt), causes selective neurodegeneration that is more severe in the striatum and cortex than in other brain regions, but the mechanism behind this selectivity is unknown. Here we report that in HD knock-in mice, the expression levels of mutant $\mathrm{Htt}(\mathrm{mHtt})$ are higher in brain tissues than in peripheral tissues. However, the expression of $\mathrm{N}$-terminal $\mathrm{mHtt}$ via stereotaxic injection of viral vectors in mice also results in greater accumulation of $\mathrm{mHtt}$ in the striatum than in muscle. We developed an in vitro assay that revealed that extracts from the striatum and cortex promote the formation of high-molecular weight (HMW) mHtt compared with the relatively unaffected cerebellar and peripheral tissue extracts. Inhibition of ubiquitin-activating enzyme E1 (Ube1) increased the levels of HMW mHtt in the relatively unaffected tissues. Importantly, the expression levels of Ubel are lower in brain tissues than peripheral tissues and decline in the nuclear fraction with age, which is correlated with the increased accumulation of $\mathrm{mHtt}$ in the brain and neuronal nuclei during aging. Our findings suggest that decreased targeting of misfolded $\mathrm{Htt}$ to the proteasome for degradation via Ube1 may underlie the preferential accumulation of toxic forms of $\mathrm{mHtt}$ in the brain and its selective neurodegeneration.
\end{abstract}

Key words: misfolding; neurodegneration; ubiquitin

\section{Introduction}

Huntington's disease (HD) is an autosomal-dominant neurodegenerative disease caused by an expansion of the polyglutamine (polyQ) tract in the huntingtin protein $(\mathrm{Htt})$. This progressive neurodegenerative disease is characterized by the loss of neurons, which is most pronounced in the striatum and cerebral cortex, resulting in symptoms such as chorea, dystonia, depression, cognitive deficits, and, in the late stage, death (Landles and Bates, 2004). A pathological hallmark of the disease is the formation of cytoplasmic and intranuclear aggregates or inclusions that consist of small N-terminal fragments of mutant $\mathrm{Htt}$ ( $\mathrm{mHtt}$; DiFiglia et al., 1997; Gutekunst et al., 1999). There are transgenic mouse models that expresses $\mathrm{N}$-terminal fragments of mutant proteins,

\footnotetext{
Received Feb. 25, 2014; revised April 24, 2014; accepted April 29, 2014.

Author contributions: B.E.W., S.L., and X.-J.L. designed research; B.E.W., C.-E.W., S.Y., K.B., and B.H. performed research; B.E.W. and X.-J.L. analyzed data; B.E.W., S.L., and X.-J.L. wrote the paper.

This work was supported by National Institutes of Health Grants AG19206 and NS041449 (to X.-J.L.); and A G031153 and NS0405016 (to S.L.). This research project was supported in part by the Viral Vector Core of the Emory National Institute of Neurological Disorders and Stroke Core Facilities Grant P30NS055077. We thank Matthew Randolph for technical assistance in muscle injection and stereotaxic surgery, Dr. Michael Epstein for recommendations in statistical analysis, Cheryl Strauss for critically reading this manuscript, and Dr. Nick Seyfried for the SUMO2/3 antibody.

The authors declare no competing financial interests.

Correspondence should be addressed to Dr. Xiao-Jiang Li, Department of Human Genetics, Emory University School of Medicine, 615 Michael Street, Room 347, Atlanta, GA 30322. E-mail: xli2@emory.edu.

DOI:10.1523/JNEUROSCI.0775-14.2014

Copyright $\odot 2014$ the authors $\quad 0270-6474 / 14 / 348411-12 \$ 15.00 / 0$
}

but develop more severe phenotypes (Davies et al., 1997; Schilling et al., 1999; Xu et al., 2013a) than HD models expressing fulllength (FL) mHtt (Slow et al., 2003; Gray et al., 2008), suggesting that smaller $\mathrm{N}$-terminal $\mathrm{mHtt}$ is more toxic than longer $\mathrm{mHtt}$ fragments. However, how N-terminal Htt fragments accumulate in the brain and cause HD pathogenesis remains to be investigated.

Although both wild-type (WT) protein and $\mathrm{mHtt}$ are ubiquitously expressed throughout the body, there is no correlation between the expression of $\mathrm{Htt}$ and the brain regions most affected by HD (Li et al., 1993; Fusco et al., 1999; Gutekunst et al., 1999; Kuemmerle et al., 1999). The role of $\mathrm{mHtt}$ aggregates and inclusions is also controversial. $\mathrm{mHtt}$ can form several types of aggregate precursors, termed oligomers or protofibrils, in a polyQ length-dependent manner (Legleiter et al., 2010) and can be found in brain tissues from HD mouse models (Sathasivam et al., 2010). The role, if any, of these mHtt oligomers in HD toxicity is still unclear, though evidence suggests that there are multimeric pools of oligomerized $\mathrm{mHtt}$ that can form aggregates with age (Marcellin et al., 2012). Since aggregate formation does not correlate well with $\mathrm{HD}$ toxicity, oligomerized $\mathrm{mHtt}$, rather than aggregated $\mathrm{mHtt}$, is suspected of being the toxic intermediary.

Despite the controversial role of $\mathrm{mHtt}$ aggregates, it is evident that these aggregates are ubiquitinated (Davies et al., 1997; DiFiglia et al., 1997; Gutekunst et al., 1999). Protein ubiquitination is initiated by ubiquitin-activating enzymes E1 (UbeE1s), which 
then pass the ubiquitinated proteins to E2-conjugating enzymes and E3 ligases for targeting to the proteasome for degradation (Schulman and Harper, 2009). Protein ubiquitination and degradation are involved in a variety of cellular functions (Kerscher et al., 2006), as well as in removing misfolded and toxic proteins in a variety of neurodegenerative diseases (Liu et al., 2007; Tan et al., 2008; Lim and Lim, 2011). However, we know very little about how ubiquitination contributes to the preferential accumulation of mutant proteins in neuronal cells. In the current study, we observed that the differential formation of high-molecular weight (HMW) mHtt and aggregates in the brain and peripheral tissues is modulated by E1-E2-E3 targeting activity and that ubiquitin-activating enzyme expression correlates with the differential accumulation of mHtt. Our findings offer new insight into the preferential accumulation of $\mathrm{mHtt}$ and its selective neurodegeneration.

\section{Materials and Methods}

Animals. Animal procedures were approved by the Institutional Animal Care and Use Committee (IACUC) of Emory University. Full-length mHtt CAG140Q [HD knock-in (KI)] mice were provided by Dr. Michael Levine (University of California, Los Angeles, Los Angeles, CA; Hickey et al., 2008) and were maintained at the Emory University Animal facility in accordance with IACUC guidelines. For stereotaxic injection of virus and behavioral studies, three female and two male mice per group were used. For the remainder of the experiments, both sexes were used.

Plasmids and antibodies. PRK vectors expressing 1-212 (N212) or 1-508 (N508) N-terminal Htt fragments containing 23Q (WT) or 120/ 150Q (mutant) were generated previously ( $\mathrm{Li}$ and $\mathrm{Li}, 1998$; Havel et al., 2011). The lentiviral vectors were constructed by adding a digested F2Aenhanced cyan fluorescent protein (ECFP) fragment to the $\mathrm{C}$ terminus of $\mathrm{Htt}$ in the PRK vector. The htt-F2A-ECFP DNA fragment was then excised and ligated into the pFUW viral backbone for viral production. The final virus was packaged and amplified by the Emory University Viral Vector Core, and expresses Htt and ECFP under the same promoter in the same cells in which F2A self-cleavage can separate Htt and ECFP proteins.

The mouse anti-Htt (mEM48) was produced previously in our laboratory (Zhou et al., 2003; Wang et al., 2008). Primary antibodies used for immunoblotting and immunoprecipitation assays were as follow: mouse anti-mHtt (mEM48), mouse 1C2 (Millipore), mouse anti-tubulin (Sigma-Aldrich), GAPDH (Ambion), P4D1 1:1000 (Cell Signaling Technology), GAPDH 1:80,000 (Millipore), eIF $\alpha$ 1:10,000 (Santa Cruz Biotechnology), vinculin 1:10,000 (Sigma), 1C2 1:10,000 (Millipore), transcription factor II B 1:1000 (Santa Cruz Biotechnology), synaptosomalassociated protein 25 1:20,000 (Sigma), K63-specific Apu3 1:1000 (Millipore), K48-linked Ubiq 1:1000 (Cell Signaling Technology), and small ubiquitin-related modifier (SUMO)-2/3 1:125 (MLB International).

Western blot analysis. Whole brains from WT and HD KI mice were dissected to isolate the cortex, striatum, and cerebellum. The tissues were homogenized for 25 strokes in ice-cold homogenization buffer (10 nM $\mathrm{Na}_{2} \mathrm{HPO}_{4}, 5$ mM EDTA, 5 mM EGTA, 0.02\% NaN3) containing a protease inhibitor mixture (Pierce Protein Biology Products, Thermo Scientific) and $100 \mu \mathrm{M}$ PMSF. For Western blotting, samples were boiled for 5 $\min$ in SDS/ $\beta$-mercaptoethanol (BME) protein loading dye and run at 50 $\mathrm{mA}$ on $4-12 \%$ Tris-Glycine gels purchased from Invitrogen (catalog \#EC60385). Proteins were transferred to a nitrocellulose membrane for $80 \mathrm{~min}$ at $105 \mathrm{~V}$ in Tris-Glycine buffer. After blocking, blots were probed with mEM48 or other primary antibodies overnight. The Western blots were developed using the ECL Prime Chemiluminescence kit (GE Healthcare). For subcellular fractionation, whole-brain cortex was collected from 4-, 8-, and 12-month-old HD CAG140 knock-in mice, and fractions ( $\mathrm{P} 1, \mathrm{P} 3$, and $\mathrm{S} 3)$ were prepared using the method of Sharp et al. (1995). Lysates were centrifuged at $1000 \times g$ for $10 \mathrm{~min}$ at $4^{\circ} \mathrm{C}$ to separate the $\mathrm{P} 1$ and $\mathrm{S} 1$. The P1 was washed again to yield the nuclear fraction. S1 was centrifuged at $17,600 \times g$ for $20 \mathrm{~min}$ at $4^{\circ} \mathrm{C}$. The $\mathrm{S} 2$ was then centrifuged at $100,000 \times g$ for $1 \mathrm{~h}$ in a swinging bucket rotor to separate the P3 (synaptosome fraction) and the S3 (soluble cytoplasm fraction). Protein samples were prepared as described earlier.

For formic acid solubilization of $\mathrm{mHtt}$ aggregates, cortex, cerebellum, and striatum were dissected out from a 7-month-old heterozygous HD CAG140 knock-in mouse. Formic acid-solubilized aggregates were obtained following procedures previously outlined (Lunkes et al., 2002; Zhou et al., 2003; Landles et al., 2010). Tissues were homogenized in ice-cold buffer (50 mm Tris- $\mathrm{HCl}, \mathrm{pH} 8.8,100 \mathrm{~mm} \mathrm{NaCl}, 5 \mathrm{~mm} \mathrm{MgCl}, 1$ mM EDTA, pH 8.0, 0.5\% NP40, plus protease inhibitors). Lysates were centrifuged at $800 \times g$ at $4^{\circ} \mathrm{C}$ to fractionate into crude nuclear and cytoplasmic fractions. SDS buffer (500 $\mu$ l, 2\% SDS, 5\% BME, 15\% glycerol, protease inhibitors) was added to the crude nuclear pellet and boiled for $10 \mathrm{~min}$. The boiled nuclear pellet was sonicated for $20 \mathrm{~s}$ at $5 \mathrm{~mA}$, and centrifuged for $15 \mathrm{~min}$ at $16,200 \times g$ at room temperature. The pellet (insoluble aggregates) was incubated in $100 \%$ formic acid with shaking $(350 \mathrm{rpm})$ at $37^{\circ} \mathrm{C}$ for $1 \mathrm{~h}$. The formic acid was removed by Vacufuge $\left(30^{\circ} \mathrm{C}, 2 \mathrm{~h}\right)$, and then the sample was reduced in $1 \mathrm{M}$ Tris Base and protease inhibitors.

Immunoblot signals were quantified using either ImageJ or UN-SCAN-IT. We used the same size section on the blots for quantification. All data have been quantified as a ratio of protein to a loading control and then normalized within the experiment.

Cell cultures. Human embryonic kidney 293 (HEK293) cells (ATCC), HD stable HEK293 cell lines fHtt-23Q, and fHtt-120Q were established previously (Zhou et al., 2003) and cultured in DMEM/F12 medium (Invitrogen) containing $10 \%(\mathrm{v} / \mathrm{v})$ fetal bovine serum, $100 \mathrm{U} / \mathrm{ml}$ penicillin, $100 \mu \mathrm{g} / \mathrm{ml}$ streptomycin (Invitrogen), and $250 \mu \mathrm{g} / \mu \mathrm{l}$ Fungizone (amphotericin B). Cells were maintained at $37^{\circ} \mathrm{C}$ in $5 \% \mathrm{CO}_{2}$ incubators. Stable cell lines were selected using $500 \mu \mathrm{g} / \mathrm{ml}$ hygromycin (Invitrogen). For transient transfections, cells were plated at $75 \%$ confluency and transfected with $1 \mu \mathrm{g}$ (for 12-well plates), $2 \mu \mathrm{g}$ (for 6-well plates), or $4 \mu \mathrm{g}$ (for $10 \mathrm{~cm}$ plates) of plasmid DNA using Lipofectamine 2000 (Invitrogen) in serum-free DMEM (Invitrogen) for $5 \mathrm{~h}$. Cells were grown in the media described above.

In vitro degradation assay. Htt HEK293 cells stably expressing transfected full-length $\mathrm{Htt}$ were grown to confluence in a $10 \mathrm{~cm}$ plate. Cells were washed in the plate then lysed in cold assay buffer $(25 \mathrm{~mm}$ Tris- $\mathrm{HCl}$, $\mathrm{pH}$ 7.6, $10 \mathrm{~mm} \mathrm{MgCl}, 100 \mu \mathrm{g} / \mathrm{ml}$ purified rabbit creatine kinase, $50 \mathrm{~mm}$ phosphocreatine, $1 \mathrm{~mm}$ ATP added at use). Wild-type mice were killed, and tissues (striatum, cerebellum, cortex, kidney, liver, heart, and muscle) were rapidly collected and homogenized at $1 \mathrm{~g} / 1 \mathrm{ml}$ in cold assay buffer using 20 strokes of a glass dounce hand homogenizer. Both cell lysates and tissues were centrifuged $500 \times g$ at $4^{\circ} \mathrm{C}$ for 5 min to pellet unbroken tissues and membranes. The supernatant was collected and stored on ice, while protein concentrations were determined using a BCA Protein Assay Kit (Thermo Scientific). Both tissue and cell lysates were prepared at $170 \mu \mathrm{g}$ protein $/ 500 \mu \mathrm{l}$ assay buffer, and the appropriate number of $200 \mu \mathrm{l}$ aliquots was prepared. The samples containing both cell and tissue lysates were mixed (200 $\mu \mathrm{l}$ cell lysates plus $200 \mu \mathrm{l}$ tissue lysates). The control samples contained equal volumes of tissue or cell lysates and assay buffer. The samples were incubated at $37^{\circ} \mathrm{C}$ with 300 rpm shaking for 0,8 , or $16 \mathrm{~h}$. The reaction was stopped by the addition of protease inhibitors, PMSF, and protein loading dye.

For inhibiting the proteasome and E1 enzymes, tissues from HD CAG140 KI mice (Menalled et al., 2003) were collected and homogenized in cold assay buffer $(25 \mathrm{~mm}$ Tris-HCl, pH 7.6, $10 \mathrm{~mm} \mathrm{MgCl}, 100 \mu \mathrm{g} / \mathrm{ml}$ purified rabbit creatine kinase, $50 \mathrm{~mm}$ phosphocreatine, and $2 \mathrm{~mm}$ ATP). Tissue lysates were prepared as in the in vitro degradation assay (IVDA) and diluted to $170 \mu \mathrm{g}$ protein $/ 500 \mu \mathrm{l}$ assay buffer, and the appropriate number of aliquots was prepared. Fifty micromolar MG132 or $50 \mu \mathrm{M}$ PYR41 (Yang et al., 2007) was added to appropriate tubes. The reaction was incubated and stopped as described above.

$q R T-P C R$ and RT-PCR. Total RNA was isolated from the HD CAG140 KI mouse cortex, striatum, cerebellum, muscle, kidney, liver, and heart using the RNeasy Lipid Tissue Mini Kit (Qiagen), and RT reactions were performed with $2 \mu \mathrm{g}$ of total RNA, as described previously (Wang et al., 2008). qRT-PCRs were performed using SYBR Select Master Mix (Applied Biosystems), and RT-PCR was performed using TaKaRa Taq. The following primers were used: primers specific for mouse and human htt 
A
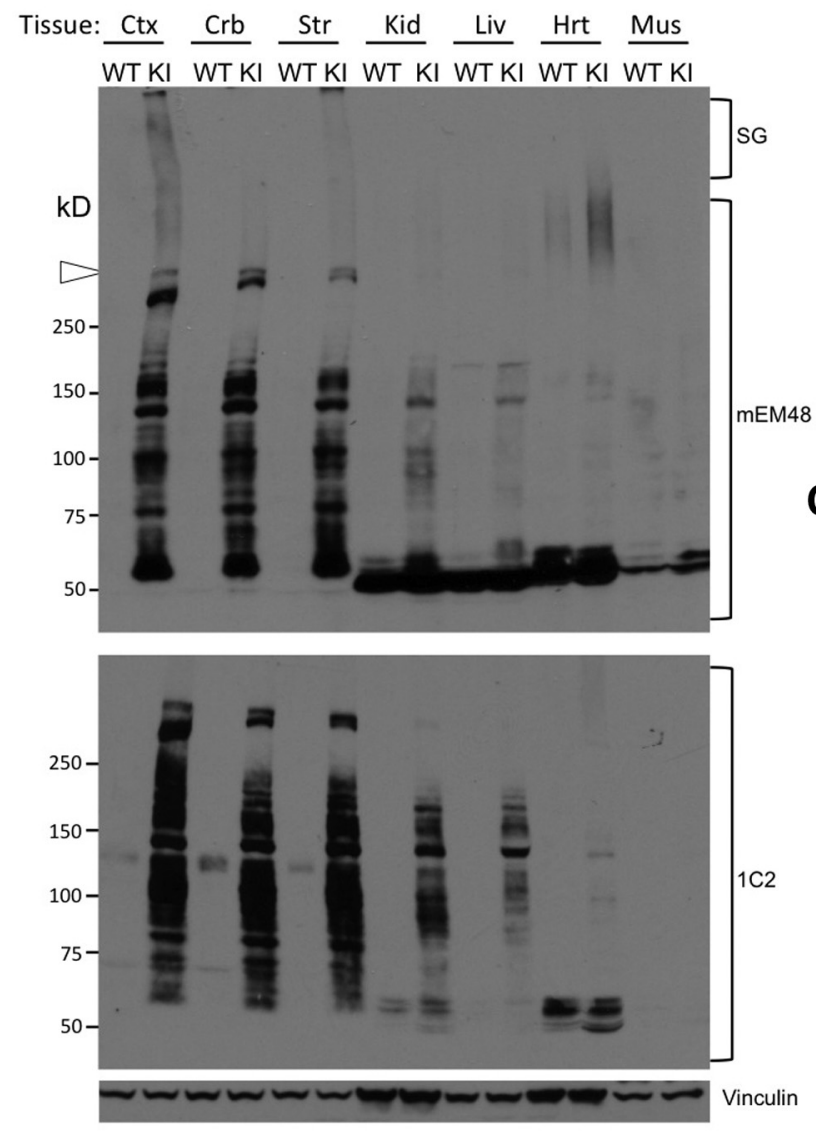

B

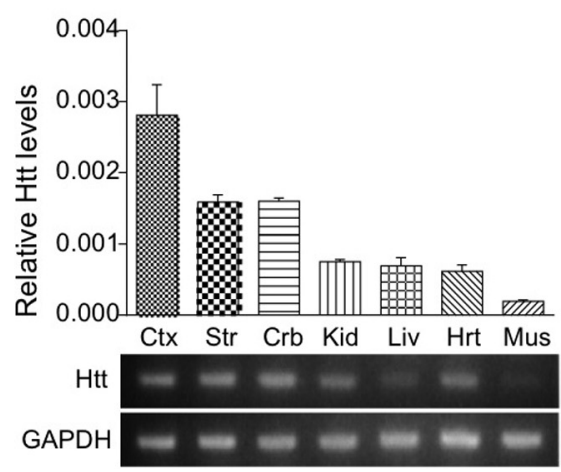

C

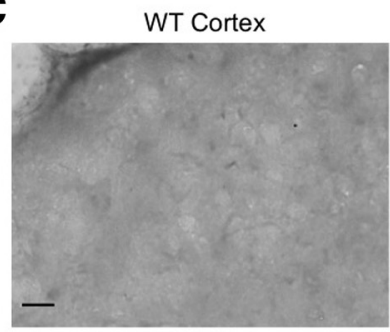

WT Kidney

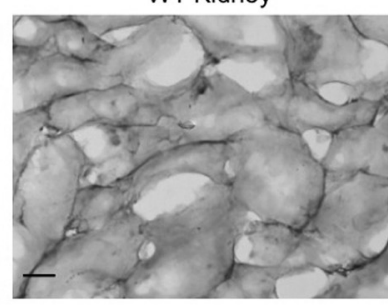

$\mathrm{KI}$ Cortex

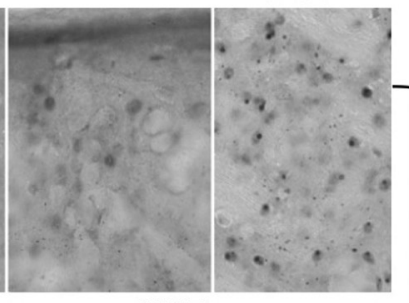

KI Kidney

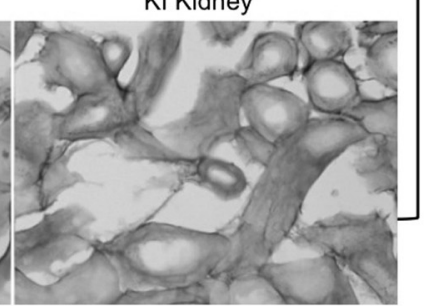

Figure 1. Differential levels of mutant huntingtin in brain and peripheral tissues of HD CAG140 KI mice. $\boldsymbol{A}$, Western blotting revealing soluble full-length (open arrowhead) mHtt in cortex (Ctx), striatum (Str), cerebellum (Crb), heart (Hrt), kidney (Kid), liver (Liv), and skeletal muscle (Mus). Western blots were probed with mEM48 (1:50), 1C2 (1:10,000), and anti-vinculin. SG, Stacking gel. $\boldsymbol{B}$, Quantitative RT-PCR assessing the expression levels of mHtt RNA in HD CAG140 KI mice. Three brain regions and four peripheral tissues (see $\boldsymbol{A}$ for abbreviations) were examined. GAPDH was used as a control. The relative Htt levels were normalized by GAPDH and calculated using $r=2^{\text {(Chtt }- \text { Cgapdh) }}(n=6)$. Error bars indicate the mean \pm SEM. The PCR products were also analyzed by staining DNA gel (bottom). C, Immunohistochemistry with anti-Htt (mEM48) of the cortex, striatum, and kidney tissues of 6-month-old HD KI mice and age-matched WT mice controls. Scale bars, $10 \mu \mathrm{m}$.

were HD1S (forward) 5' -ATGGCGACCCTGGAAAAGCT-3' and HD40A (reverse) 5'-TGCTGCTGGAAGGACTTGAG-3'; GAPDH mRNA was detected using GAPDH 958S (forward) 5'-AACTTTGTCAAGCTCATTTCCTGGT-3' and GAPDH 1032A (reverse) 5' GGTTTCTTACTCCTTGGAGGCCATG-3'. The following PCR cycles were used: $94^{\circ} \mathrm{C}$ for $3 \mathrm{~min} ; 94^{\circ} \mathrm{C}$ for $45 \mathrm{~s}, 64^{\circ} \mathrm{C}$ for $45 \mathrm{~s}, 72^{\circ} \mathrm{C}$ for $60 \mathrm{~s}(30$ cycles for qRT-PCR, 28 cycles for RT-PCR); and $72^{\circ} \mathrm{C}$ for $10 \mathrm{~min}$.

Stereotaxic injection. Three-month-old wild-type mice $(\mathrm{C} 3 \mathrm{H})$ were anesthetized using $0.39 \mathrm{ml} / 20 \mathrm{~g} 2.5 \%$ avertin. The animals were injected in either the right hemisphere or bilaterally with $1.5 \mu \mathrm{l}\left(1.08 \times 10^{12}\right)$ lentivirus per side with the following coordinates set from the bregma: 2 $\mathrm{mm}$ lateral, $0.6 \mathrm{~mm}$ anterior, and $-3.3 \mathrm{~mm}$ ventral. The flow rate was 200 nanoliters/min, and there was a 3 min delay before the needle was slowly removed. The animals were monitored daily and administered the analgesic ketoprofen (Fort Dodge Animal Health) at $2 \mathrm{mg} / \mathrm{ml}$ for $3 \mathrm{~d}$ postsurgery.

For muscle injection, mice were anesthetized using $0.39 \mathrm{ml} / 20 \mathrm{~g} 2.5 \%$ avertin (Alfa Aesar), and $1.5 \mu \mathrm{l}$ of virus was diluted to $50 \mu \mathrm{l}$ and injected into the calf muscle using a $100 \mu \mathrm{l}$ Hamilton syringe with a $27 \mathrm{~g}$ disposable needle. Analgesics were administered as described.

Rotarod assay. Animals were tested on a Rotamex Rotarod (Columbus Instruments) three times per day on 3 consecutive days. After a constant slow rotation, the speed was increased gradually over the course of 10 min from 5 revolutions/s to 30 revolutions/s. Data from all $3 \mathrm{~d}$ were averaged and used for comparison of each group.

Statistical analyses. Quantifications of Western blots were obtained using ImageJ. The repeated-measures two-way ANOVA and two-way
ANOVA were performed using Prism version 6.0 (GraphPad). An $\alpha$ of $\leq 0.05$ was considered to be significant.

\section{Results}

$\mathrm{mHtt}$ is more stable in brain than peripheral tissues

$\mathrm{mHtt}$ is ubiquitously expressed; however, HD is characterized by neurological symptoms and degeneration in specific regions of the brain. This selective neurodegeneration has been a longstanding issue for researchers to address since it does not correlate directly with $\mathrm{Htt}$ expression levels or observed protein aggregation (Li et al., 1993; Fusco et al., 1999; Gutekunst et al., 1999; Kuemmerle et al., 1999). We first compared mHtt expression levels in brain and peripheral tissues in a HD CAG140Q knock-in mouse model, which expresses full-length mHtt under the control of the endogenous mouse Htt promoter and shows the progressive phenotypic development and formation of $\mathrm{mHtt}$ aggregates (Menalled et al., 2003; Hickey et al., 2008). Western blotting revealed a different array of $\mathrm{mHtt}$ fragments in each tissue from a 7-month-old HD KI mouse (Fig. 1A). FL mHtt (open arrow) appears to be less stable in peripheral tissues as we were unable to detect it by immunoblotting with either the antibody to N-terminal Htt (mEM48) or antibody to expanded polyQ repeats (1C2). Fewer $\mathrm{N}$-terminal mHtt fragments were seen in the peripheral tissues than in brain regions, suggesting that $\mathrm{mHtt}$ proteolysis may be different between brain and periph- 


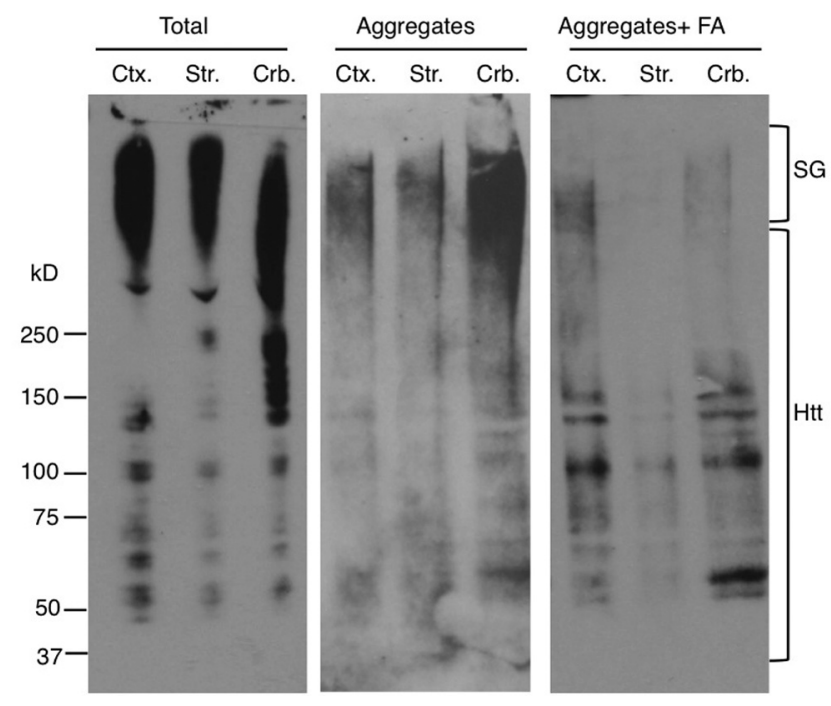

Figure 2. Formation of $\mathrm{Htt}$ aggregates by $\mathrm{N}$-terminal $\mathrm{mHtt}$ fragments in $\mathrm{HD} \mathrm{KI}$ mouse brain. Western blot analysis of total tissue lysates of the cortex (Ctx.), striatum (Str.), and cerebellum (Crb.) of HD KI mouse. Different amounts of aggregated Htt were purified. Dissolving these Htt aggregates with formic acid (FA) resulted in multiple $\mathrm{N}$-terminal $\mathrm{Htt}$ fragments that were revealed by mEM48 antibody blotting. SG, Stacking gel.

eral tissues. We then performed qRT-PCR to quantify the levels of $\mathrm{mHtt}$ mRNA relative to GAPDH mRNA (Fig. $1 B$ ). There were higher levels of mHtt mRNA in all three brain regions than in the peripheral tissues, and mHtt is expressed at the lowest level in muscle. Immunohistochemistry with mEM48 revealed the accumulation and aggregation of $\mathrm{mHtt}$ in the cortex and striatum in 6-month-old HD KI mice, whereas there was no obvious $\mathrm{mHtt}$ staining signal by mEM48 in the kidney (Fig. 1C). Together, these data suggest that there are differences in mRNA expression and the post-translational modification of $\mathrm{mHtt}$ in the brain and in peripheral tissues, which contribute to the differential accumulation, aggregation, and subsequent toxicity of $\mathrm{mHtt} \mathrm{N}$-terminal fragments.

We also purified $\mathrm{Htt}$ aggregates from the cortex, striatum, and cerebellum of HD KI mice at the age of 7 months using formic acid treatment to dissolve aggregates. We found that aggregates in different brain regions are formed by multiple $\mathrm{N}$-terminal $\mathrm{Htt}$ fragments, which are the same in different brain regions (Fig. 2). Thus, the accumulation and aggregation of $\mathrm{mHtt}$ in different brain regions are unlikely to be due to intrinsic proteolysis differences of $\mathrm{Htt}$, but rather result from tissue-specific factors that modulate the stability of these N-terminal Htt fragments.

\section{mHtt is more stable and forms more HMW mHtt in tissues affected in $\mathrm{HD}$ in vitro}

To better understand the early steps in the accumulation of $\mathrm{mHtt}$, we designed an IVDA that allows us to observe tissue-specific processing of $\mathrm{mHtt}$ by adding the same amount of $\mathrm{mHtt}$ to cellular lysates from different tissues. FL Htt proteins containing either 23Q or 120Q in transfected HEK293 cells (Zhou et al., 2003) were used as a source of Htt. Lysates from individual tissues (striatum, kidney, liver, heart, and skeletal muscle) in wild-type mice were incubated with transfected Htt to test tissue-specific effects of modulation on Htt levels, stability, and aggregation. The tissue lysates in a Tris buffer contained creatine kinase, phosphocreatine, and ATP (TCP-ATP buffer), which are necessary for energy-dependent protein post-translational modifications. After incubation for different times, the transfected $\mathrm{Htt}$ and lysates were subjected to Western blotting (Fig. $3 A$ ). We then quantified the relative levels of $\mathrm{mHtt}$ on Western blots by measuring its ratio to vinculin, a cytoskeletal protein that is stable even after a long incubation time. We found that FL 120Q (open arrowhead) and $\mathrm{N}$-terminal $\mathrm{mHtt}$ fragments are more stable in the striatal lysate than in the lysates from most peripheral tissues observed (Fig. $3 B, C)$. Two-way ANOVA using time and tissue type as separate variables revealed that the length of incubation time contributed the most to $\mathrm{mHtt}$ degradation $(11.66 \%$; $p=3.29 \mathrm{E}-6)$, whereas tissue type contributed $6.851 \%$ to the degradation $(p=0.8137)$ across all groups. Multiple comparisons show that the decrease in $\mathrm{mHtt}$ reaches significance in the kidney $(p=0.0351)$ and liver $(p=0.0012)$ lysates at $16 \mathrm{~h}$, and in the muscle at both 8 and $16 \mathrm{~h}$ ( $p=0.0003$ and $p=5.26 \mathrm{E}-7)$. However, the decrease in mHtt was not significant at either 8 or $16 \mathrm{~h}$ in the striatal or heart lysates.

Noticeably, HMW mHtt (Fig. $3 B, C$, filled arrowhead) was formed in the above in vitro assay. Two-way ANOVA suggests that tissue type contributed the most to oligomerized mHtt formation in the striatum compared with the periphery, accounting for $42.57 \%$ of the effect ( $p=0.0013$ ). The incubation time accounted for only $8.139 \%$ of total variance $(p=3.85 \mathrm{E}-7)$, with an interaction between the two factors $(20.57 \%, p=2.70 \mathrm{E}-5)$. HMW mHtt formation is significantly higher at 8 and $16 \mathrm{~h}$ of incubation in the striatum compared with all four peripheral tissue lysates ( $8 \mathrm{~h}: p=6.10 \mathrm{E}-6,1.81 \mathrm{E}-6,7.76 \mathrm{E}-7$, and 7.33E-7; $16 \mathrm{~h}: p=$ 2.70E-6, 1.79E-7, 2.85E-7, and 3.30E-5). HMW mHtt formation did not reach significance in any of the peripheral tissues.

When comparing brain regions, the lysates from cortex and cerebellum yielded a significant decrease in $\mathrm{mHtt}$ at $16 \mathrm{~h}$ incubation $(p=0.0364$ and $p=0.0109)$, but there was no significant decrease with striatal lysates (Fig. $3 D, E$ ). This analysis suggests that $\mathrm{mHtt}$ is more stable in vitro with the striatal lysates than with the other tissue lysates. When comparing HMW mHtt in different brain regions (Fig. $3 D, E$ ), tissue type contributed $38.48 \%$ to the formation of HMW mHtt ( $p=5.61 \mathrm{E}-5)$, while incubation time contributed $21.86 \%$ of the effect ( $p=5.99 \mathrm{E}-7$ ), and $28.48 \%$ of the effect on oligomer formation is caused by an interaction between the two variables $(p=1.54 \mathrm{E}-5)$. Multiple-comparison tests allowed us to see that more HMW mHtt was formed in the cortex and striatum lysates than in the cerebellum lysates at $16 \mathrm{~h}$ of incubation ( $p=3.73 \mathrm{E}-9$ and $p=0.0301)$. No HMW mHtt was formed in control samples without brain tissue lysates (Fig. 3D, first two lanes). These data show that in vitro the striatal tissue is less able to clear mHtt than the other tissues tested, and therefore more HMW mHtt is formed with the striatal lysates. This difference is consistent with the preferential accumulation of $\mathrm{mHtt}$ in the striatum of HD KI mice (Lin et al., 2001; Menalled et al., 2003) and the selective vulnerability of striatal neurons in HD.

\section{$\mathrm{N}$-terminal $\mathrm{mHtt}$ is more stable in the brain than in the muscle and causes motor dysfunction}

Since HD mouse models suggest that small N-terminal fragments of $\mathrm{mHtt}$ are more toxic than full-length $\mathrm{mHtt}$ (Heng et al., 2008), we chose to examine the degradation and HMW mHtt formation of N-terminal mHtt fragments in the brain and peripheral tissues. Lentiviral constructs expressing N-terminal fragments of WT mice and mHtt under the ubiquitin promoter (UBC) were injected into the striatum and skeletal muscle. Muscle was chosen for comparison with brain because it, like neurons, is also a terminally differentiated tissue. The three viral vectors (Fig. 4A) that were used express a small N-terminal Htt fragment with 23Q (N212-23Q) or 120Q (N212-120Q), or a larger N-terminal $\mathrm{mHtt}$ fragment (N508-120Q). Viruses were injected into the 
A

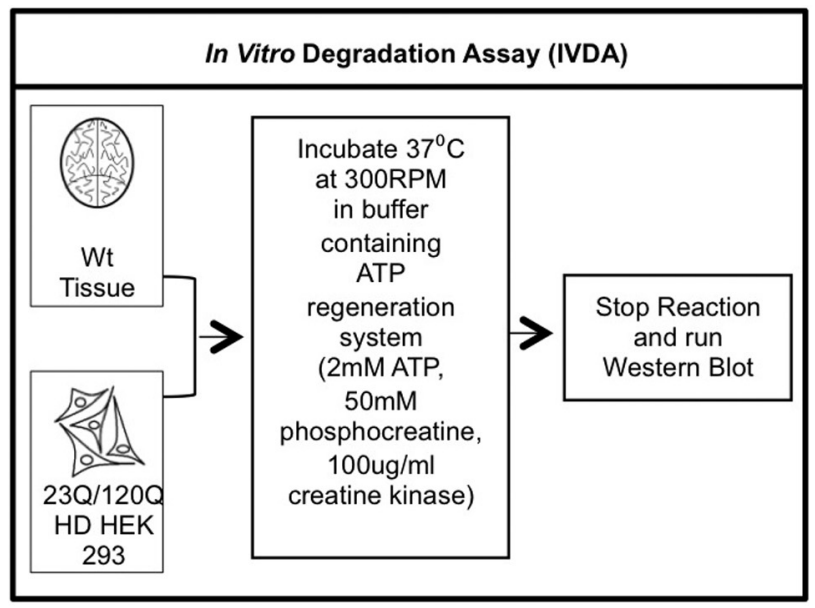

C

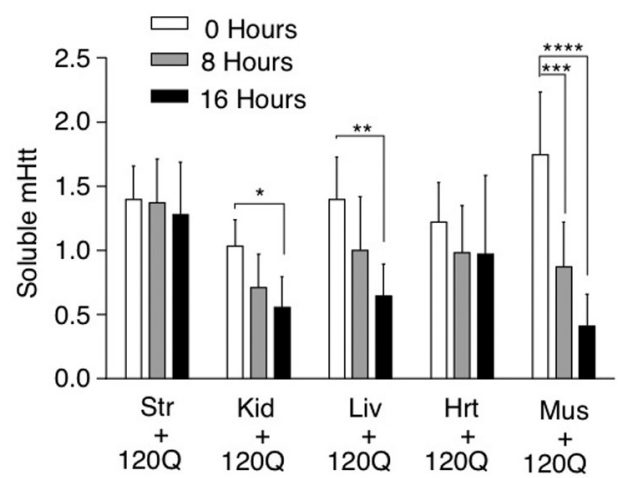

D

\begin{tabular}{|c|c|c|c|c|c|c|}
\hline \multicolumn{4}{|c|}{ Tissue/Cells Only } & \multicolumn{3}{|c|}{ Tissue + FL-120Q } \\
\hline 1200 & Str & Ctx & $\mathrm{Crb}$ & Str & Ctx & $\mathrm{Crb}$ \\
\hline
\end{tabular}

Hours: $\begin{array}{lllllllllllllll}0 & 16 & 0 & 16 & 0 & 16 & 0 & 16 & 0 & 16 & 0 & 16 & 0 & 16\end{array}$

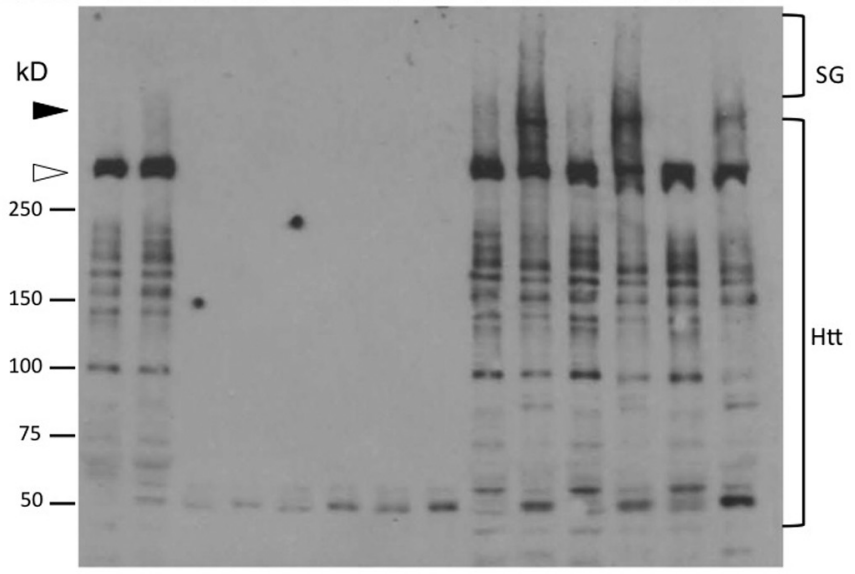

$-\infty-\ldots-\cdots-\cdots$ Vinculin
B

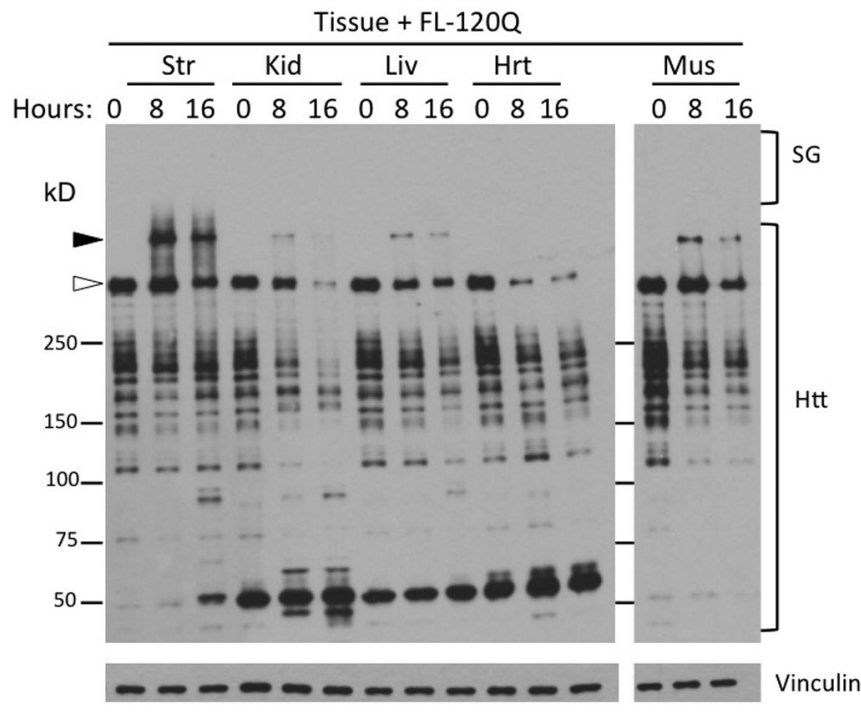




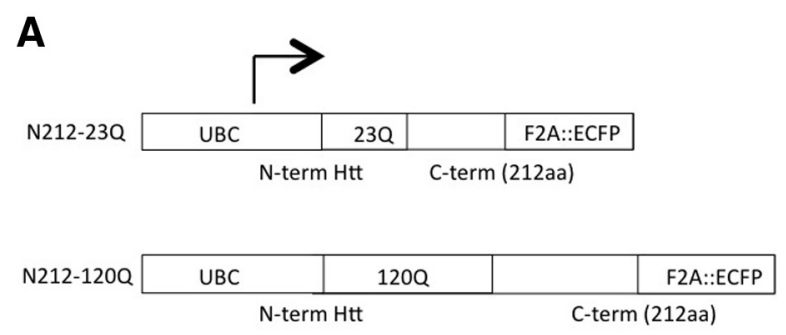

\begin{tabular}{|c|c|c|c|}
\hline N508-120Q & $120 Q$ & F2A::ECFP \\
\hline
\end{tabular}

B

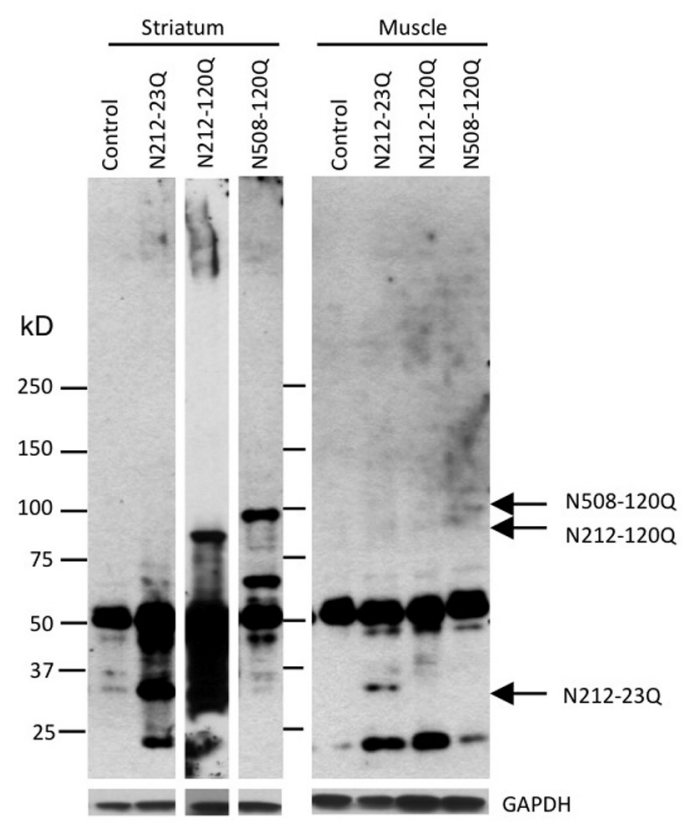

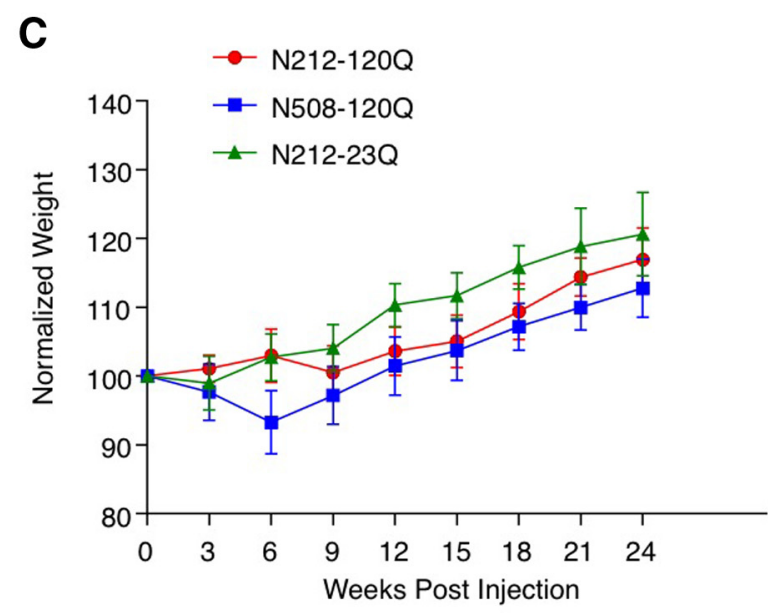

D
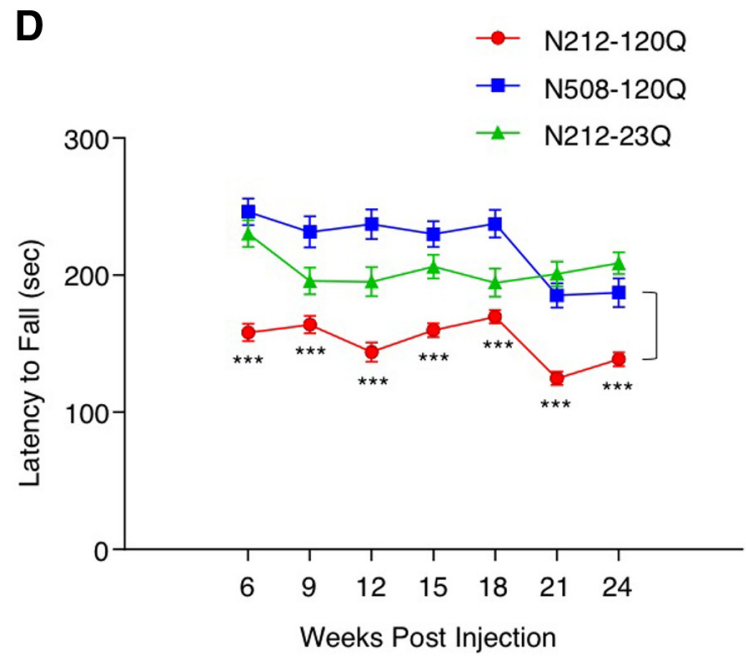

Figure 4. Stability and toxicity of $\mathrm{N}$-terminal $\mathrm{mHtt}$ fragments in vivo. $\boldsymbol{A}$, Schematic of lentiviral constructs. Htt is linked with ECFP via F2A, a peptide linker that can be self-cleaved in cells to separate $\mathrm{mHtt}$ from ECFP. Constructs are expressed under the control of the ubiquitin promoter (UBC). $\boldsymbol{B}$, Western blot analysis of the striatum and muscle tissues that had been injected with lentiviral $\mathrm{mHtt}$ for $1 \mathrm{month}$. The blots were probed with mEM48 (1:50) to detect $\mathrm{mHtt}$ expression. $\boldsymbol{C}, \boldsymbol{D}$, Body weights $(\boldsymbol{C})$ and rotarod performance $(\boldsymbol{D})$ of mice injected with lentiviral $\mathrm{mHtt}$ into their striatum were normalized to initial weight before surgery. Error bars indicate the mean \pm SEM $(n=5$ per group). Statistical significance determined using repeated-measures two-way ANOVA with multiple testing (Bonferroni test). The $p$ value shown $(* * * 00.001$ ) is between $N 212-1200$ and N508 $-120 Q$, as indicated by the bracket.

striatum and the right calf muscle ( $n=3$ per group) of 3-monthold WT mice. One month postinjection, the injected tissues were isolated for Western blot analysis. All three transgenic Htt proteins were expressed clearly in the striatum of the injected mice, while we detected no or very little mHtt protein (N212-120Q and N508-120Q) in the skeletal muscle by Western blotting, despite a low level of normal N-terminal Htt (N212-23Q) (Fig. 4B). Importantly, the shorter N-terminal mHtt (N212-120Q) formed more aggregated htt than N508-120Q in the striatum, suggesting that the smaller $\mathrm{N}$-terminal Htt fragment is more prone to misfolding (Fig. 4B). These in vivo data agree with observations from

(figure legend continued.) incubation $(n=4)$, and were normalized within the experiment to allow comparison between experiments. D, Comparison of the striatum (Str) with cortex (Ctx) and cerebellum (Crb) for their ability to process full-length $\mathrm{mHtt}$ by IVDA. Controls are cellular lysates only and tissue lysates only. Kid, Kidney; Liv, liver; Hrt, heart; Mus, muscle. E, All soluble $\mathrm{mHtt}$ fragments and full-length $\mathrm{mHtt}$ (top) and HMW $\mathrm{mHtt}$ (bottom) in $\boldsymbol{D}$ were quantified as a ratio to vinculin and normalized. Error bars indicate mean \pm SEM, and statistical significance was determined using repeated-measures two-way ANOVA with (Fisher's LSD test) multiple testing $\left({ }^{*} p<0.05,{ }^{* *} p<0.01,{ }^{* * *} p<0.001\right.$; see text for exact $p$ values). our in vitro experiments that $\mathrm{N}$-terminal $\mathrm{mHtt}$ is more stable in the brain than in the muscle.

Next, we examined the in vivo toxicity of these mHtt fragments using the rotarod as a test of motor function. WT mice ( $n=5$ per group) were injected bilaterally with these viral $\mathrm{Htt}$ vectors in the striatum and were used for longitudinal study. There was no significant difference in body weights among the three groups injected with viral vectors expressing different $\mathrm{N}$-terminal Htt, though mice injected with $\mathrm{mHtt}$ show slightly less weight gain than mice injected with normal $\mathrm{N}$-terminal $\mathrm{Htt}$ (Fig. 4C). One month postinjection, animals for the behavioral studies were trained for the rotarod test, and then examined at 6 weeks and once every 3 weeks afterward (Fig. 4D). Two-way ANOVA analysis revealed that Htt fragment contributed the most variance $(20.09 \%, p=2.48 \mathrm{E}-21)$, and time, while accounting for only $3.76 \%$ of the effect, was still considered significant ( $p=1.04 \mathrm{E}-9)$. Mice injected with viral N212-120Q Htt performed worse than those with N508-120Q at all time points or weeks (w) postinjection. ( $6 \mathrm{w}, p=4.45 \mathrm{E}-12 ; 9 \mathrm{w}, p=1.44 \mathrm{E}-7 ; 12 \mathrm{w}, p=$ $2.09 \mathrm{E}-13 ; 15 \mathrm{w}, p=4.29 \mathrm{E}-8 ; 18 \mathrm{w}, p=1.23 \mathrm{E}-7 ; 21 \mathrm{w}, p=2.71 \mathrm{E}-6$; $24 \mathrm{w}, p=0.0002)$. This increased toxicity of N212-120Q is also 
A

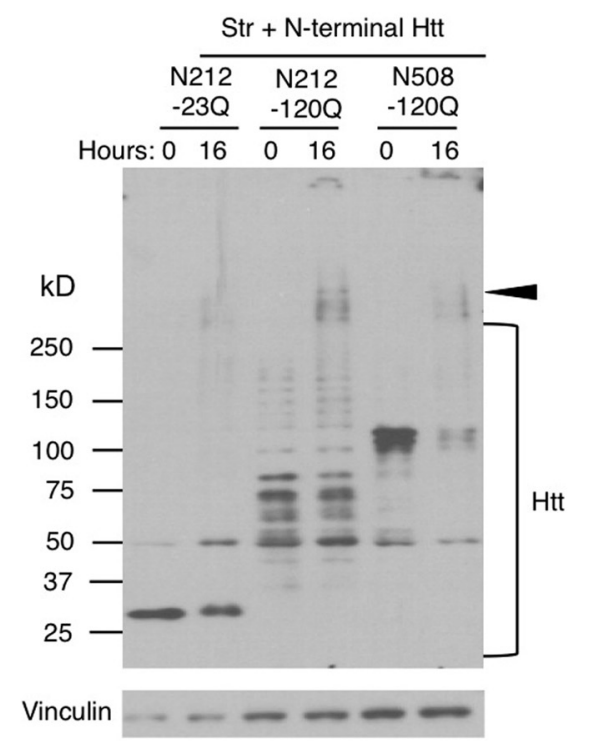

C

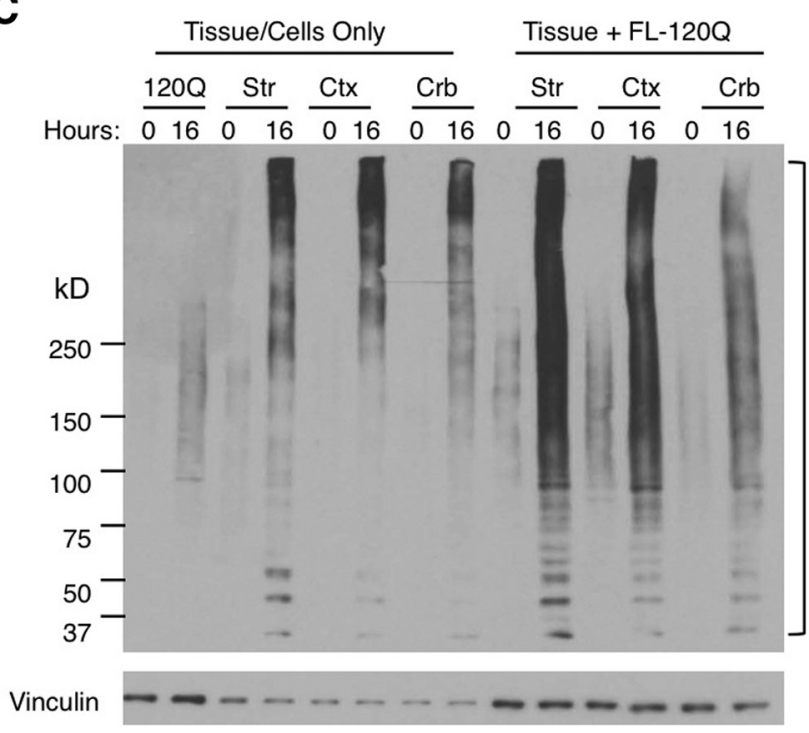

Brain Region IVDA

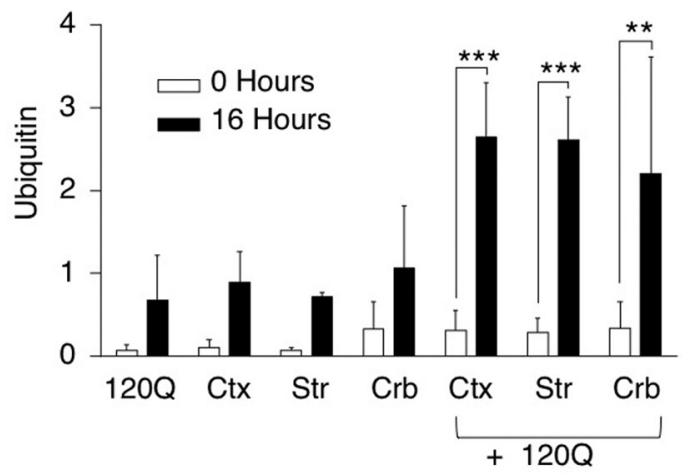

B

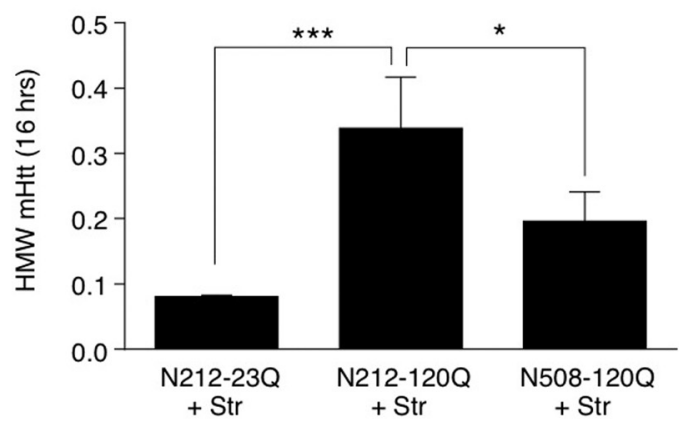

Tissue + FL-120Q

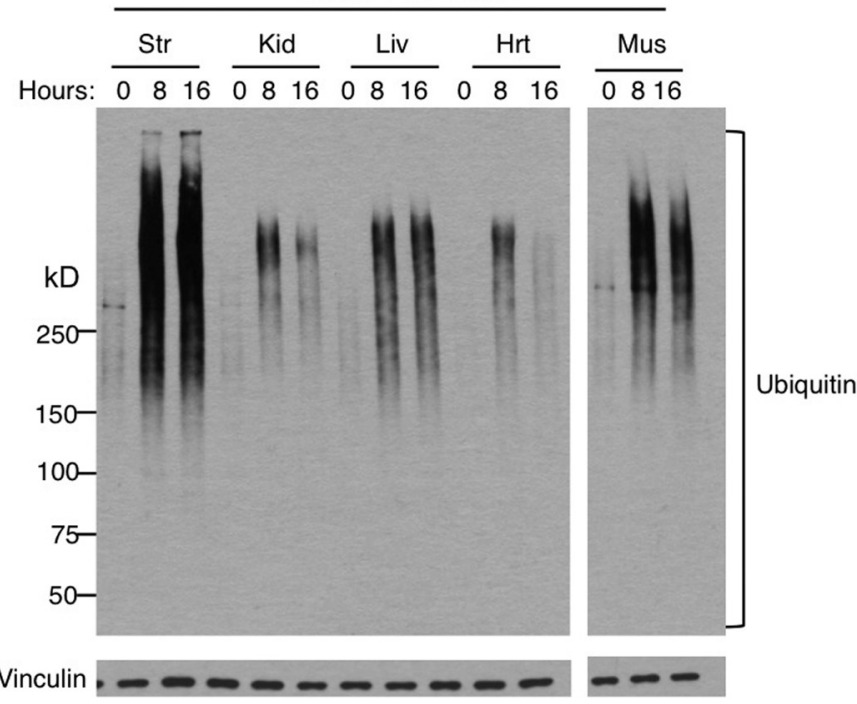

Brain to Periphery IVDA

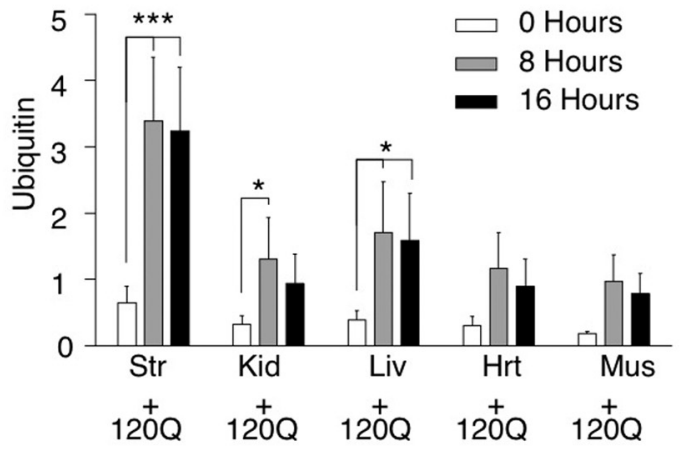

Figure 5. In vitro degradation of N-terminal mHtt fragments. $A, B, \mathrm{~N}$-terminal fragments of $\mathrm{Htt}(\mathrm{N} 212-23 \mathrm{Q}, \mathrm{N} 212-120 \mathrm{Q}$, and $\mathrm{N} 508-120 \mathrm{Q})$ in transfected cell lysates were incubated with wild-type mouse striatal tissues in IVDA. Western blots $(\boldsymbol{A})$ are shown, along with quantification of HMW mHtt $(\boldsymbol{B})$ by two-way ANOVA with Bonferroni's multiple testing. Error bars indicate the mean $\pm \operatorname{SEM}\left({ }^{*} p<0.05,{ }^{* * *} p<0.001\right)$. C, Western blot analysis of in vitro ubiquitination in brain and peripheral tissues. Total ubiquitin is compared among cortex, striatum, cerebellum, and peripheral tissues. Western blots are representative $(n=3$ ) of IVDA with anti-ubiquitin (P4D1 1:1000). D, Quantification of total ubiquitin at 0, 8, and 16 h of incubation. Ubiquitin was quantified as a ratio to the loading control (vinculin) then normalized within the experiment. Error bars indicate the mean \pm SEM, and statistical significance was determined using repeated-measures two-way ANOVA with multiple testing ( ${ }^{*} p<0.05,{ }^{* *} p<0.01,{ }^{* * *} p<0.001$, see text for exact $p$ values). Str, Striatum; (tx, cortex; Crb, cerebellum; Kid, kidney; Liv, liver; Hrt, heart; Mus, muscle. 
A
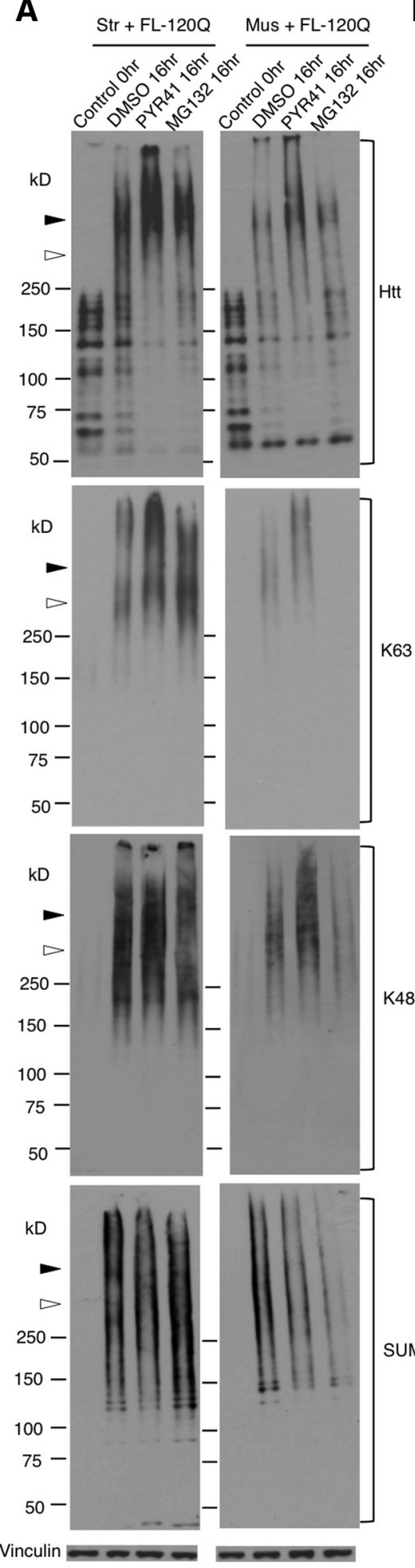

K48
B
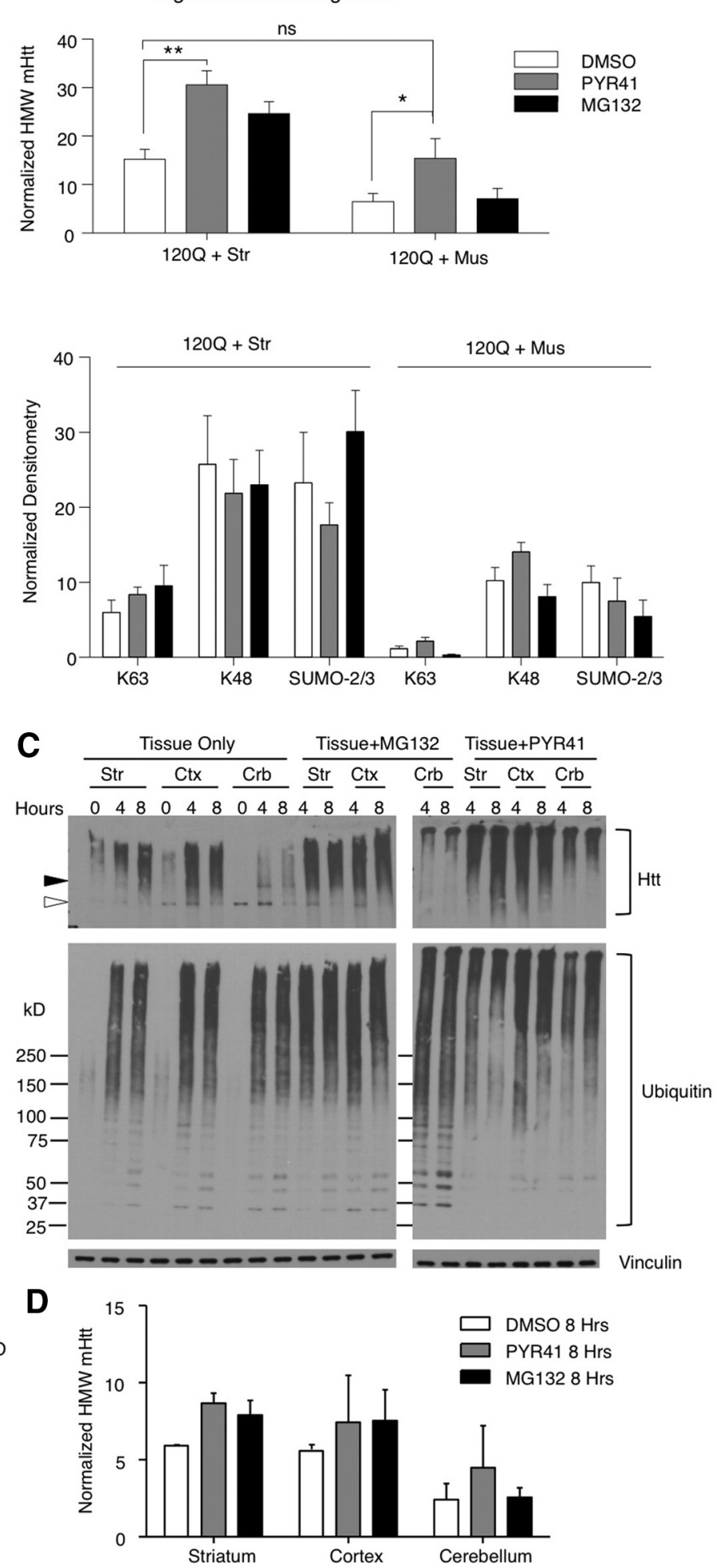

Figure 6. Promotion of the formation of HMW mHtt and accumulation by inhibiting ubiquitin-activating enzyme E1. $A$, Western blot is representative of three independent experiments (mEM48 1:50). Striatal tissue lysates (left) or muscle tissue lysates (right) were incubated with transfected full-length $\mathrm{mHtt}$ (FL-120Q) for 0 and $16 \mathrm{~h}$ with the addition of DMS0, the E1 inhibitor PYR41 ( $50 \mu \mathrm{m}$ ), or the UPS inhibitor MG132 (50 $\mu \mathrm{m})$. Open arrowhead, Full-length $\mathrm{mHtt}$; filled arrowhead, mHtt oligomers; Control, lysates before incubation. Blots were probed with (from top to bottom) antibodies to htt (mEM48), $\alpha-K 63, \alpha-K 48$, and SUM0-2/3. B, Quantification of HMW mHtt (top), and $\alpha-K 63, \alpha-K 48$, and SUM0-2/3 (bottom) at $16 \mathrm{~h}$ is shown ( $n=3$ ). The ratio of HMW mHtt to vinculin was used for quantification. Error bars indicate the mean $\pm \mathrm{SEM}$, and statistical significance was determined using repeated-measures two-way ANOVA with (Tukey's test) multiple testing $\left({ }^{*} p<0.05,{ }^{* *} p<0.01\right)$. C, HD KI mouse tissue lysates were incubated in vitro in IVDA buffer and treated with the E1 inhibitor PYR41 (50 $\left.\mu \mathrm{m}\right)$ or the UPS inhibitor MG132 (50 $\left.\mu \mathrm{m}\right)$. Western blotting showing that PYR41 or MG132 increased the accumulation of oligomerized mHtt in the cerebellar tissue compared with no drug treatment (left). Striatal tissue samples were also included for comparison with peripheral tissues (right). D, Quantification of the ratio of oligomerized $\mathrm{mHtt}$ to vinculin after in vitro incubation at $8 \mathrm{~h}$ then normalized within the experiment. Error bars indicate the mean \pm SEM $(n=3)$. Str, Striatum; Mus, muscle; Ctx, cortex; Crb, cerebellum. 
A

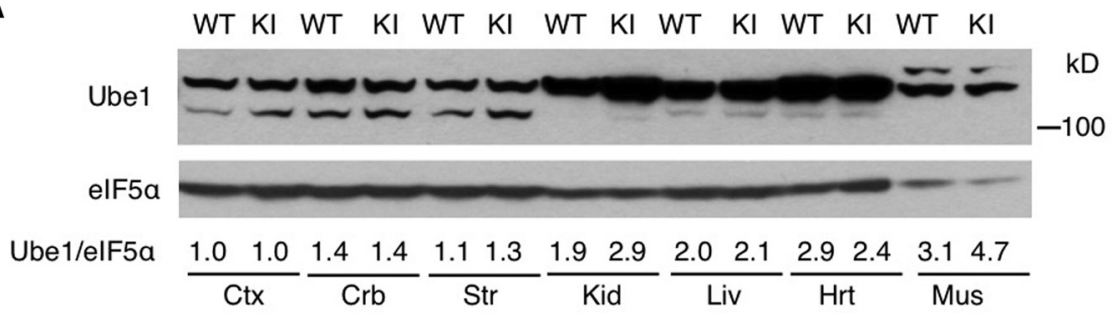

B

WT Total Nuclear Cytoplasm Synaptosome

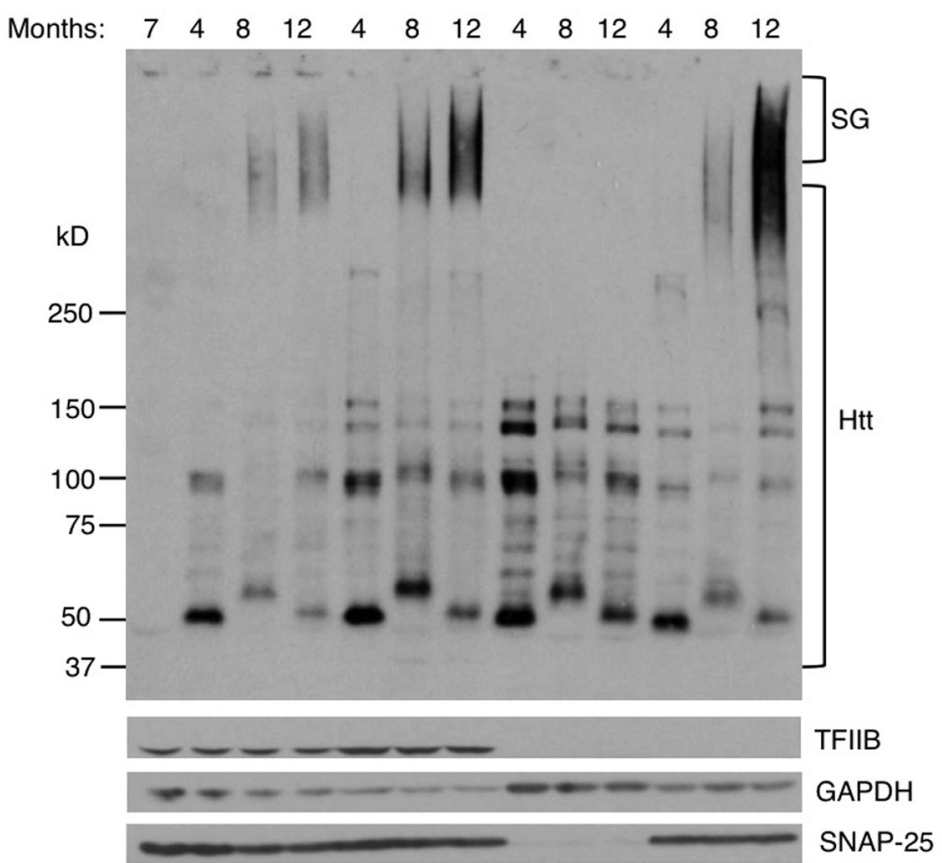

C

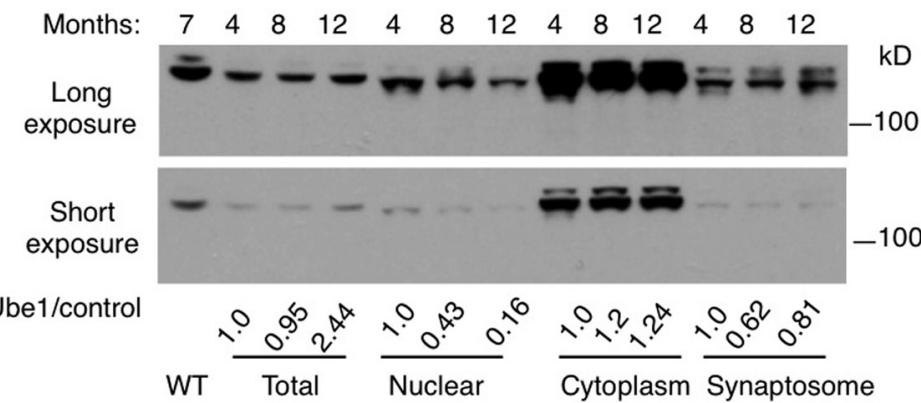

Figure 7. Differential levels of Ube 1 in brain and peripheral tissues. $A$, Western blot analysis of Ube 1 in the brain and peripheral tissues of WT and HD KI mice. The ratios of Ube1 (bottom) to the loading control are shown beneath the blot. $\boldsymbol{B}$, Western blot analysis of subcellular fractionations of HD KI mice at different ages. The blot was probed with anti-Htt (mEM48). The HMW mHtt increases in the nuclear and synaptosomal fractions from the aged HD KI mice. $\boldsymbol{C}$, The blot in $\boldsymbol{B}$ was probed with anti-Ube1, and immunoblot signals from short and long exposure times are presented. The ratios of Ube 1 to that at 4 months are shown beneath the blot. Ctx, Cortex; Str, striatum; Crb, cerebellum; Kid, kidney; Liv, liver; Hrt, heart; Mus, muscle.

consistent with the increased stability and aggregation of N212120Q in the injected striatum seen by Western blotting (Fig. 4B).

\section{Ubiquitinated $\mathrm{mHtt}$ is increased in brain tissues}

Given the differential toxicity and stability of N-terminal Htt, it was important to examine how striatal tissues modulate different fragments of mHtt. Thus, we incubated transfected Htt (N21223Q, N212-120Q, and N508-120Q) with mouse striatal lysates. More HMW mHtt was formed by N212-120Q (Fig. 5A). Quan- tification by densitometry shows that oligomer formation by N212-120Q is significantly higher than HMW $\mathrm{mHtt}$ formation by N508-120Q ( $p=0.0374)$ and N212-23Q ( $p=0.0007$; Fig. $5 B)$. This result suggests that HMW $\mathrm{mHtt}$ is formed readily by shorter $\mathrm{N}$-terminal $\mathrm{mHtt}$ fragments.

Given the findings that N-terminal $\mathrm{mHtt}$ is more stable in the striatum and forms more HMW mHtt, we wanted to know whether there are differences in $\mathrm{Htt}$ ubiquitination in different brain regions and peripheral tissues using the IVDA. We compared total ubiquitin levels at 0 and $16 \mathrm{~h}$ after incubation of full-length $\mathrm{mHtt}$ (FL-120Q) with cortex, striatum, and cerebellum tissue lysates. Western blots with anti-ubiquitin (P4D1) revealed that the incubation markedly increased protein ubiquitination in striatal lysates (Fig. 5C). Although the incubation also increased protein ubiquitination in brain tissue lysates without FL-120Q, adding FL-120Q markedly increased protein ubiquitination (Fig. 5C, left). Thus, this increase reflects mHtt ubiquitination in IVDA. Importantly, striatal lysates resulted in more ubiquitination than cortex and cerebellar lysates, and brain tissue lysates yielded greater ubiquitination than peripheral tissue lysates (Fig. 5C), which was also verified by quantitative analysis of the relative levels of ubiquitin on the blots (Fig. 5D). The peripheral tissues incubated with FL-120Q also showed a rise in total ubiquitin levels at $8 \mathrm{~h}$ and then a decrease at $16 \mathrm{~h}$ of incubation, though the ubiquitin levels are lower than those with brain tissue lysates. Two-way ANOVA showed that incubation time contributed the most to ubiquitination $(32.25 \%, p=2.01 \mathrm{E}-5)$, and tissue type contributed $23.76 \%$ of the variance observed in all groups ( $p=$ 0.0930, not significant; Fig. 5D). These differences can be interpreted in the following two ways: one is that ubiquitinated proteins could be cleared more easily in the peripheral tissues; and the other is that more ubiquitinated proteins are generated in the brain than in the peripheral tissues.

Inhibiting ubiquitin-activating enzyme E1 promotes aggregate formation

To determine how differences in ubiquitination could contribute to the stability of $\mathrm{mHtt}$, we inhibited ubiquitination using the drug PYR41, a cell-permeable pyrazone compound that is reported to irreversibly inhibit ubiquitin-activating enzyme E1 activity (Yang et al., 2007; Guan and Ricciardi, 2012; Su et al., 2013; $\mathrm{Xu}$ et al., 2013b). The IVDA was then performed using striatal and muscle lysates mixed with full-length mHtt (FL-120Q), with the addition of $50 \mu \mathrm{M}$ PYR41. For comparison, the ubiquitin- 


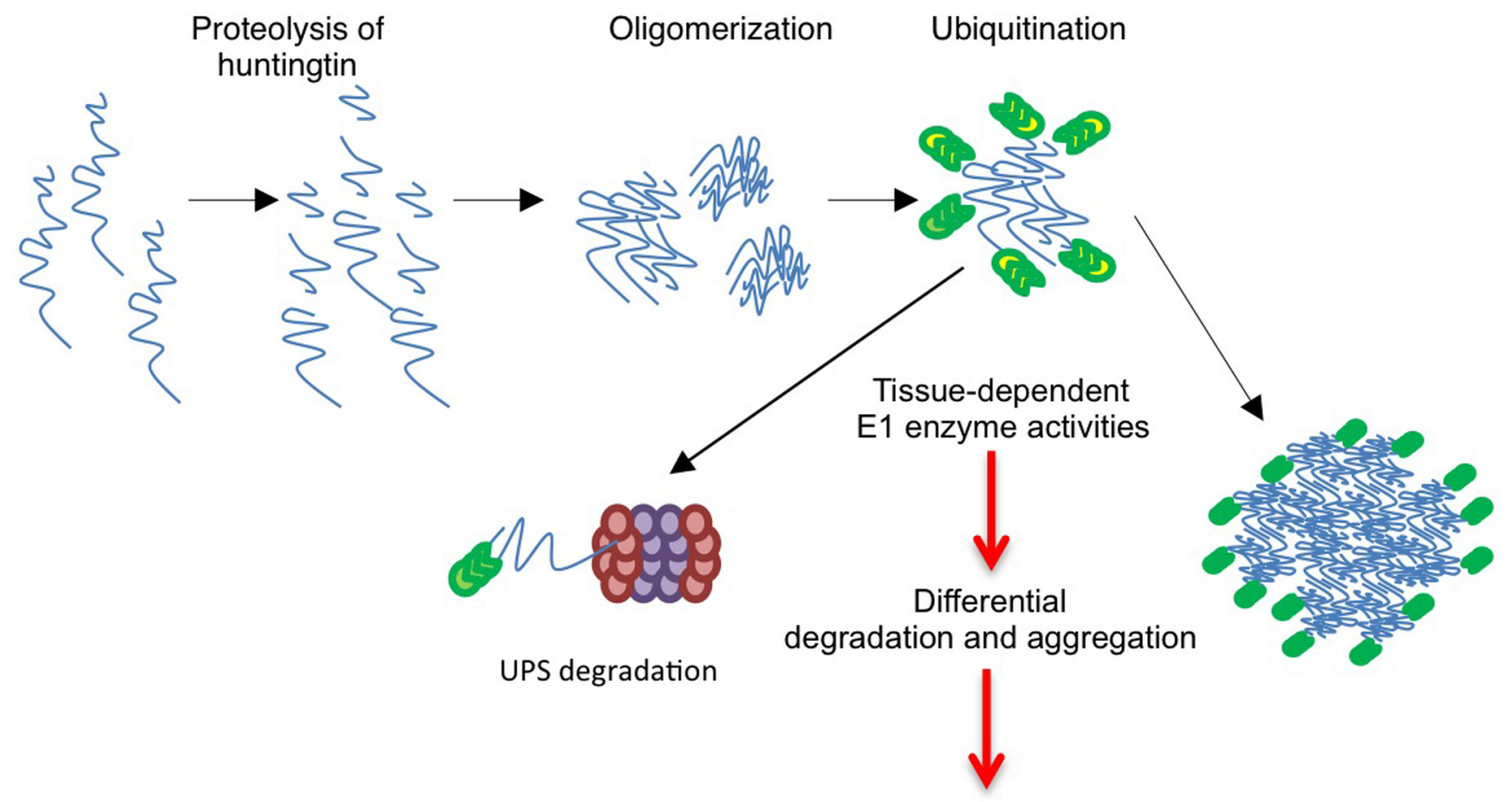

Differential cell death

Figure 8. A proposed model for the differential accumulation of $\mathrm{mHtt}$ in affected brain regions. $\mathrm{mHtt}$ is cleaved to form fragments, which can form HMW mHtt and be ubiquitinated. Differential targeting of the ubiquitinated $\mathrm{mHtt}$ to the proteasome can lead to different levels of misfolded proteins. In striatal neurons, the reduced targeting of ubiquitinated Htt to the proteasome is likely to contribute to the preferential accumulation of $\mathrm{mHtt}$ in these cells, affecting the cells and forming aggregates. Ube 1 activity and other targeting proteins account for the differential accumulation of $\mathrm{mHtt}$ in different brain regions and subcellular compartments.

proteasome system (UPS) inhibitor MG132 (50 $\mu \mathrm{M})$ was used to inhibit protein degradation by the proteasome. The blots were probed with Htt, K48 ubiquitin, K63 ubiquitin, and sumoylation antibodies. PYR41 caused greater generation of HMW $\mathrm{mHtt}$ in both the striatal and muscle mixtures than MG132 (Fig. 6A). Quantification of densitometry verified that PYR41 treatment of both striatal and muscle tissues increased HMW $\mathrm{mHtt}(p=$ 0.0015 and $p=0.0454$, respectively) to a greater extent than MG132 (Fig. 6B). To compare the levels of HMW mHtt formed by endogenous full-length $\mathrm{mHtt}$ in the striatum, cortex, and cerebellum, we used brain tissue lysates from HD KI mice to perform IVDA with MG132 or PYR41 treatment. The immunoblots were probed with anti-Htt and anti-ubiquitin to detect HMW $\mathrm{mHtt}$ and ubiquitinated proteins. Although total ubiquitinated proteins do not seem different between the drug-treated samples and the control without drug treatment, both MG132 and PYR41 appear to increase the level of HMW $\mathrm{mHtt}$ in the striatum and cortex (Fig. 6C,D, top). The lower level of HMW mHtt was seen with the cerebellar lysates than with the striatal and cortical lysates, which was also increased by PYR41. However, these increases are not statistically significance due to large variations in the limited number of experiments $(n=3)$. Given that PYR41 blocks the degradation of ubiquitinated proteins by the ubiquitin-proteasome system (Yang et al., 2007), these results suggest that PYR41 may prevent the targeting of HMW mHtt to the proteasome, resulting in increased levels of HMW $\mathrm{mHtt}$.

Ubiquitin-activating enzyme $\mathrm{E} 1$ is expressed at different levels in brain and peripheral tissues

Given the above in vitro data, it was important to investigate whether Ubel activity is correlated with the accumulation of $\mathrm{mHtt}$ in the brain. We therefore performed Western blot analysis of brain and peripheral tissues with known differential levels of $\mathrm{mHtt}$ in HD KI mice (Fig. 1). Using an antibody to Ube1 and comparing the ratio of Ube1 to eIF5 $\alpha$, a translational protein that is expressed in all of the types of cells used and is involved in translation elongation, cell cycle progression, and actin dynamics (Si et al., 1996), we found that the expression levels of Ube1 are markedly lower in brain tissues than in peripheral tissues (Fig. $7 A$ ). The levels of Ube1 are also lower in the striatum (Ube1/ eIF5 $\alpha: 1.2$ ) and cortex (1.0) than in the cerebellum (1.4). There is no difference in Ube1 expression between HD KI and WT mouse tissues (Fig. 7A), suggesting that mHtt does not impair the expression of Ube1. If Ube1 expression is indeed critical for the levels of $\mathrm{mHtt}$, we should also see low levels of it in the nucleus and nerve terminals in which $\mathrm{mHtt}$ preferentially accumulates and forms aggregates. We next performed subcellular fractionation experiments using $\mathrm{HD} \mathrm{KI}$ mice at 4, 8, and 12 months of age, and found that the aggregated $\mathrm{mHtt}$ is increased in the nuclear and synaptosomal fractions from the older HD KI mice (Fig. 7B). More importantly, Ube1 levels are indeed lower in the nuclear and synaptosomal fractions than in the cytosolic fraction (Fig. 7C). Compared with the level of Ubela at 4 months, the nuclear Ubel level significantly declines with age (from 1.0 to 0.16 ), while synaptosomal Ube 1 levels remain unchanged. This difference suggests that Ube1 activity is also important for the age-dependent accumulation of mHtt in neuronal nuclei, whereas other synaptic modulators may alter $\mathrm{mHtt}$ accumulation and aggregation in synapses during aging.

Based on the above findings and the fact that E1 enzymes target ubiquitinated proteins for degradation via the proteasome, we propose that differential E1 enzyme activities in different 
types of tissues and cells contribute to the differential accumulation of mHtt and its aggregation in neuronal cells. Reduced E1 enzyme activities may explain why $\mathrm{mHtt}$ preferentially accumulates in the brain, and forms aggregates in the nucleus and synapses (Fig. 8).

\section{Discussion}

The selective neurodegeneration seen in a variety of neurodegenerative diseases has long been a puzzle. Understanding how mutant proteins selectively accumulate in the affected brain regions would help us to understand this important and unresolved issue. In the present study, we developed a novel in vitro assay that allows us to closely monitor the accumulation of $\mathrm{mHtt}$ in different tissues. This IVDA demonstrates that $\mathrm{mHtt}$ is more stable in the brain than in peripheral tissues. Our findings here suggest that reduced targeting of misfolded $\mathrm{mHtt}$ to the proteasome for degradation may contribute to the preferential accumulation of $\mathrm{mHtt}$ in affected neurons and the selective neuronal vulnerability in individuals with HD.

We also found that mHtt mRNA expression is in general lower in the peripheral tissues than in brain regions. This difference could also help to explain the increased toxicity of $\mathrm{mHtt}$ in neuronal cells. However, by expressing the same viral $\mathrm{mHtt}$ vectors in the striatum and muscles, we still saw more abundant accumulation of $\mathrm{mHtt}$ in the striatum. In addition, in different brain regions, such as the cortex and striatum, more mHtt mRNA is expressed in the cortex than in the striatum, though more and earlier accumulation of $\mathrm{mHtt}$ and aggregates are seen in the striatum in HD KI mice (Li et al., 2000, 2001; Lin et al., 2001). Thus, post-translational modification of $\mathrm{mHtt}$ appears to be important for the differential accumulation of misfolded forms of $\mathrm{mHtt}$, at least in brain regions.

Using HD KI mice, we verified that aggregated htt is formed by small $\mathrm{N}$-terminal $\mathrm{mHtt}$. By injection of viral vectors expressing $\mathrm{N}$-terminal $\mathrm{mHtt}$ into mice, we also confirmed that $\mathrm{N}$-terminal $\mathrm{mHtt}$ fragments are toxic and can become misfolded and aggregated, causing motor dysfunction. The IVDA shows that tissues from the striatum, which is most severely affected in HD, promotes the formation of HMW $\mathrm{mHtt}$ by $\mathrm{N}$-terminal $\mathrm{mHtt}$ to a greater extent than tissues from relatively unaffected regions and organs. At least two possibilities could explain this phenomenon. One is that striatal tissue favors the generation of HMW or misfolded $\mathrm{mHtt}$, and the other is that HMW Htt is more stable or less efficiently cleared in the striatum.

The ubiquitin-proteasome system plays a major role in clearing misfolded proteins, a process that involves multienzyme cascades. The first step of ubiquitin activation is mediated by the E1 enzymes that bind ATP and ubiquitin, and catalyze ubiquitin C-terminal acyl-adenylation. The active ubiquitin is then passed by E1 enzymes to E2-conjugating enzymes and then to E3 ubiquitin ligases, a reaction that is necessary for targeting of ubiquitinated proteins to the proteasome for degradation (Schulman and Harper, 2009). PYR41, a commercially available cell-permeable inhibitor, was found in a high-throughput screening of an E1E2-E3 cascade (Yang et al., 2007); it does not affect ubiquitination of proteins, but blocks the degradation of ubiquitinated proteins by the proteasome (Yang et al., 2007), giving us a useful tool to examine the targeting of ubiquitinated proteins to the proteasome for degradation. PYR41 appears to increase the accumulation of $\mathrm{mHtt}$ to a greater extent than MG132 treatment, suggesting that PYR41 may also inhibit the targeting of ubiquitinated $\mathrm{mHtt}$ to other degradation systems, such as autophagy. In fact, autophagy can also degrade ubiquitinated proteins (Shaid et al., 2013). Although whether PYR41 affects autophagy function remains to be investigated, our findings suggest that reduced degradation of misfolded $\mathrm{mHtt}$ accounts for the increased accumulation of $\mathrm{mHtt}$ in neuronal cells.

Strong evidence in support of our hypothesis is that the expression levels of E1 enzyme Ube1 are lower in brain tissues than in peripheral tissues. The lower levels of Ube1 are consistent with the increased levels of $\mathrm{mHtt}$ in brain tissues and in vitro results after inhibiting Ube1 by PYR41. The correlation between the decreased levels of Ube1 and the increased amount of ubiquitinated $\mathrm{mHtt}$ in the brain suggests that the high levels of Ube1 may be required for targeting the ubiquitinated proteins to the proteasome for degradation more efficiently, whereas the ubiquitination of proteins can be maintained with a low level of Ube1. The reduced levels of Ubel in the brain also suggest that this enzyme is expressed at a lower level in neuronal cells. We should point out that the clearance of misfolded proteins by the ubiquitin-proteasome system is a complex process involving many targeting proteins. For example, there are eight E1-activating enzymes to initiate ubiquitination (Schulman and Harper, 2009) and numerous E3 ligases for substrate-specific targeting (Ardley and Robinson, 2005). It remains to be investigated whether there are tissue- or cell type-specific proteins involved in targeting $\mathrm{mHtt}$ to the proteasome. Also, since there are different subcellular localizations of the E1 isoforms (Grenfell et al., 1994), whether different subcellular localizations of these proteins account for the differential accumulation of $\mathrm{mHtt}$ in the nucleus and synapses remains to be determined. Such proteins could be additional modulators to alter the degradation of $\mathrm{mHtt}$ in brain regions, as well as nerve terminals and different subcellular compartments. However, the intrinsic lower levels of Ube1 in brain tissues than peripheral tissues has broad implications for the selective accumulation of misfolded proteins in the brain in a variety of neurodegenerative diseases, including Alzheimer's and Parkinson's diseases. Furthermore, the IVDA assay we developed could be used to identify tissue-specific proteins that modulate the degradation of misfolded proteins in other polyQ and neurodegenerative diseases.

\section{References}

Ardley HC, Robinson PA (2005) E3 ubiquitin ligases. Essays Biochem 41: 15-30. CrossRef Medline

Davies SW, Turmaine M, Cozens BA, DiFiglia M, Sharp AH, Ross CA, Scherzinger E, Wanker EE, Mangiarini L, Bates GP (1997) Formation of neuronal intranuclear inclusions underlies the neurological dysfunction in mice transgenic for the HD mutation. Cell 90:537-548. CrossRef Medline

DiFiglia M, Sapp E, Chase KO, Davies SW, Bates GP, Vonsattel JP, Aronin N (1997) Aggregation of huntingtin in neuronal intranuclear inclusions and dystrophic neurites in brain. Science 277:1990-1993. CrossRef Medline

Fusco FR, Chen Q, Lamoreaux WJ, Figueredo-Cardenas G, Jiao Y, Coffman JA, Surmeier DJ, Honig MG, Carlock LR, Reiner A (1999) Cellular localization of huntingtin in striatal and cortical neurons in rats: lack of correlation with neuronal vulnerability in Huntington's disease. J Neurosci 19:1189-1202. Medline

Gray M, Shirasaki DI, Cepeda C, André VM, Wilburn B, Lu XH, Tao J, Yamazaki I, Li SH, Sun YE, Li XJ, Levine MS, Yang XW (2008) Fulllength human mutant huntingtin with a stable polyglutamine repeat can elicit progressive and selective neuropathogenesis in BACHD mice. J Neurosci 28:6182-6195. CrossRef Medline

Grenfell SJ, Trausch-Azar JS, Handley-Gearhart PM, Ciechanover A, Schwartz AL (1994) Nuclear localization of the ubiquitin-activating enzyme, E1, is cell-cycle-dependent. Biochem J 300:701-708. Medline

Guan H, Ricciardi RP (2012) Transformation by E1A oncoprotein involves ubiquitin-mediated proteolysis of the neuronal and tumor repressor REST in the nucleus. J Virol 86:5594-5602. CrossRef Medline 
Gutekunst CA, Li SH, Yi H, Mulroy JS, Kuemmerle S, Jones R, Rye D, Ferrante RJ, Hersch SM, Li XJ (1999) Nuclear and neuropil aggregates in Huntington's disease: relationship to neuropathology. J Neurosci 19: 2522-2534. Medline

Havel LS, Wang CE, Wade B, Huang B, Li S, Li XJ (2011) Preferential accumulation of $\mathrm{N}$-terminal mutant huntingtin in the nuclei of striatal neurons is regulated by phosphorylation. Hum Mol Genet 20:1424-1437. CrossRef Medline

Heng MY, Detloff PJ, Albin RL (2008) Rodent genetic models of Huntington disease. Neurobiol Dis 32:1-9. CrossRef Medline

Hickey MA, Kosmalska A, Enayati J, Cohen R, Zeitlin S, Levine MS, Chesselet MF (2008) Extensive early motor and non-motor behavioral deficits are followed by striatal neuronal loss in knock-in Huntington's disease mice. Neuroscience 157:280-295. CrossRef Medline

Kerscher O, Felberbaum R, Hochstrasser M (2006) Modification of proteins by ubiquitin and ubiquitin-like proteins. Annu Rev Cell Dev Biol 22:159180. CrossRef Medline

Kuemmerle S, Gutekunst CA, Klein AM, Li XJ, Li SH, Beal MF, Hersch SM, Ferrante RJ (1999) Huntington aggregates may not predict neuronal death in Huntington's disease. Ann Neurol 46:842-849. CrossRef Medline

Landles C, Bates GP (2004) Huntingtin and the molecular pathogenesis of Huntington's disease. Fourth in molecular medicine review series. EMBO Rep 5:958-963. CrossRef Medline

Landles C, Sathasivam K, Weiss A, Woodman B, Moffitt H, Finkbeiner S, Sun B, Gafni J, Ellerby LM, Trottier Y, Richards WG, Osmand A, Paganetti P, Bates GP (2010) Proteolysis of mutant huntingtin produces an exon 1 fragment that accumulates as an aggregated protein in neuronal nuclei in Huntington disease. J Biol Chem 285:8808-8823. CrossRef Medline

Legleiter J, Mitchell E, Lotz GP, Sapp E, Ng C, DiFiglia M, Thompson LM, Muchowski PJ (2010) Mutant huntingtin fragments form oligomers in a polyglutamine length-dependent manner in vitro and in vivo. J Biol Chem 285:14777-14790. CrossRef Medline

Li H, Li SH, Johnston H, Shelbourne PF, Li XJ (2000) Amino-terminal fragments of mutant huntingtin show selective accumulation in striatal neurons and synaptic toxicity. Nat Genet 25:385-389. CrossRef Medline

Li H, Li SH, Yu ZX, Shelbourne P, Li XJ (2001) Huntingtin aggregateassociated axonal degeneration is an early pathological event in Huntington's disease mice. J Neurosci 21:8473-8481. Medline

Li SH, Li XJ (1998) Aggregation of N-terminal huntingtin is dependent on the length of its glutamine repeats. Hum Mol Genet 7:777-782. CrossRef Medline

Li SH, Schilling G, Young WS 3rd, Li XJ, Margolis RL, Stine OC, Wagster MV, Abbott MH, Franz ML, Ranen NG (1993) Huntington's disease gene (IT15) is widely expressed in human and rat tissues. Neuron 11:985-993. CrossRef Medline

Lim KL, Lim GG (2011) K63-linked ubiquitination and neurodegeneration. Neurobiol Dis 43:9-16. CrossRef Medline

Lin CH, Tallaksen-Greene S, Chien WM, Cearley JA, Jackson WS, Crouse AB, Ren S, Li XJ, Albin RL, Detloff PJ (2001) Neurological abnormalities in a knock-in mouse model of Huntington's disease. Hum Mol Genet 10:137144. CrossRef Medline

Liu C, Fei E, Jia N, Wang H, Tao R, Iwata A, Nukina N, Zhou J, Wang G (2007) Assembly of lysine 63-linked ubiquitin conjugates by phosphorylated alpha-synuclein implies Lewy body biogenesis. J Biol Chem 282: 14558-14566. CrossRef Medline

Lunkes A, Lindenberg KS, Ben-Haïem L, Weber C, Devys D, Landwehrmeyer GB, Mandel JL, Trottier Y (2002) Proteases acting on mutant huntingtin generate cleaved products that differentially build up cytoplasmic and nuclear inclusions. Mol Cell 10:259-269. CrossRef Medline

Marcellin D, Abramowski D, Young D, Richter J, Weiss A, Marcel A, Maassen J, Kauffmann M, Bibel M, Shimshek DR, Faull RL, Bates GP, Kuhn RR, Van der Putten PH, Schmid P, Lotz GP (2012) Fragments of HdhQ150 mutant huntingtin form a soluble oligomer pool that declines with aggregate deposition upon aging. PLoS One 7:e44457. CrossRef Medline

Menalled LB, Sison JD, Dragatsis I, Zeitlin S, Chesselet MF (2003) Time course of early motor and neuropathological anomalies in a knock-in mouse model of Huntington's disease with 140 CAG repeats. J Comp Neurol 465:11-26. CrossRef Medline

Sathasivam K, Lane A, Legleiter J, Warley A, Woodman B, Finkbeiner S, Paganetti P, Muchowski PJ, Wilson S, Bates GP (2010) Identical oligomeric and fibrillar structures captured from the brains of R6/2 and knock-in mouse models of Huntington's disease. Hum Mol Genet 19:65-78. CrossRef Medline

Schilling G, Becher MW, Sharp AH, Jinnah HA, Duan K, Kotzuk JA, Slunt HH, Ratovitski T, Cooper JK, Jenkins NA, Copeland NG, Price DL, Ross CA, Borchelt DR (1999) Intranuclear inclusions and neuritic aggregates in transgenic mice expressing a mutant $\mathrm{N}$-terminal fragment of huntingtin. Hum Mol Genet 8:397-407. CrossRef Medline

Schulman BA, Harper JW (2009) Ubiquitin-like protein activation by E1 enzymes: the apex for downstream signalling pathways. Nat Rev Mol Cell Biol 10:319-331. CrossRef Medline

Shaid S, Brandts CH, Serve H, Dikic I (2013) Ubiquitination and selective autophagy. Cell Death Differ 20:21-30. CrossRef Medline

Sharp AH, Loev SJ, Schilling G, Li SH, Li XJ, Bao J, Wagster MV, Kotzuk JA, Steiner JP, Lo A (1995) Widespread expression of Huntington's disease gene (IT15) protein product. Neuron 14:1065-1074. CrossRef Medline

Si K, Das K, Maitra U (1996) Characterization of multiple mRNAs that encode mammalian translation initiation factor 5 (eIF-5). J Biol Chem 271:16934-16938. CrossRef Medline

Slow EJ, van Raamsdonk J, Rogers D, Coleman SH, Graham RK, Deng Y, Oh R, Bissada N, Hossain SM, Yang YZ, Li XJ, Simpson EM, Gutekunst CA, Leavitt BR, Hayden MR (2003) Selective striatal neuronal loss in a YAC128 mouse model of Huntington disease. Hum Mol Genet 12:15551567. CrossRef Medline

Su H, Chen M, Sands JM, Chen G (2013) Activation of the cAMP/PKA pathway induces UT-Al urea transporter monoubiquitination and targets it for lysosomal degradation. Am J Physiol Renal Physiol 305:F1775F1782. CrossRef Medline

Tan JM, Wong ES, Kirkpatrick DS, Pletnikova O, Ko HS, Tay SP, Ho MW, Troncoso J, Gygi SP, Lee MK, Dawson VL, Dawson TM, Lim KL (2008) Lysine 63-linked ubiquitination promotes the formation and autophagic clearance of protein inclusions associated with neurodegenerative diseases. Hum Mol Genet 17:431-439. CrossRef Medline

Wang CE, Tydlacka S, Orr AL, Yang SH, Graham RK, Hayden MR, Li S, Chan AW, Li XJ (2008) Accumulation of N-terminal mutant huntingtin in mouse and monkey models implicated as a pathogenic mechanism in Huntington's disease. Hum Mol Genet 17:2738-2751. CrossRef Medline

Xu H, Luo P, Zhao Y, Zhao M, Yang Y, Chen T, Huo K, Han H, Fei Z (2013b) Iduna protects HT22 cells from hydrogen peroxide-induced oxidative stress through interfering poly(ADP-ribose) polymerase-1-induced cell death (parthanatos). Cell Signal 25:1018-1026. CrossRef Medline

Xu Q, Huang S, Song M, Wang CE, Yan S, Liu X, Gaertig MA, Yu SP, Li H, Li S, Li XJ (2013a) Synaptic mutant huntingtin inhibits synapsin-1 phosphorylation and causes neurological symptoms. J Cell Biol 202:11231138. CrossRef Medline

Yang Y, Kitagaki J, Dai RM, Tsai YC, Lorick KL, Ludwig RL, Pierre SA, Jensen JP, Davydov IV, Oberoi P, Li CC, Kenten JH, Beutler JA, Vousden KH, Weissman AM (2007) Inhibitors of ubiquitin-activating enzyme (E1), a new class of potential cancer therapeutics. Cancer Res 67:9472-9481. CrossRef Medline

Zhou H, Cao F, Wang Z, Yu ZX, Nguyen HP, Evans J, Li SH, Li XJ (2003) Huntingtin forms toxic $\mathrm{NH} 2$-terminal fragment complexes that are promoted by the age-dependent decrease in proteasome activity. J Cell Biol 163:109-118. CrossRef Medline 